\title{
WHOLE-PLANT CONCEPT AND ENVIRONMENT RECONSTRUCTION OF A TELEMACHUS CONIFER (VOLTZIALES) FROM THE TRIASSIC OF ANTARCTICA
}

\author{
Benjamin Bomfleur, ${ }^{1, *}$ Anne-Laure Decombeix $†$ Ignacio H. Escapa, $\neq$ Andrew B. Schwendemann,* and Brian Axsmith§ \\ *Department of Ecology and Evolutionary Biology, University of Kansas, Lawrence, Kansas 66045, U.S.A., and Natural History Museum and \\ Biodiversity Institute, University of Kansas, Lawrence, Kansas 66045, U.S.A.; †Université Montpellier 2, Unité Mixte de Recherche \\ Botanique et Bioinformatique de I'Architecture des Plantes (UMR AMAP), Montpellier, F-34000, France, and Centre National \\ de la Recherche Scientifique, UMR AMAP, Montpellier, F-34000, France; ¥Consejo Nacional de Investigaciones Científicas y \\ Técnicas-Museo Paleontologico Egidio Feruglio, Trelew, Chubut 9100, Argentina; and §Department \\ of Biological Sciences, LSCB 124, University of South Alabama, Mobile, Alabama 36688, U.S.A.
}

\begin{abstract}
We present a whole-plant concept for a genus of voltzialean conifers on the basis of compression/impression and permineralized material from the Triassic of Antarctica. The reconstruction of the individual organs is based on a combination of organic connections, structural correspondences, similarities in cuticles and epidermal morphologies, co-occurrence data, and ex situ palynology. The affiliated genera of organs include trunks, branches, and roots (Notophytum); strap-shaped leaves with parallel venation (Heidiphyllum compressions and permineralized Notophytum leaves); seed cones (Telemachus and Parasciadopitys); pollen cones (Switzianthus); and bisaccate pollen of Alisporites type. Structural similarities lead us to suggest that Parasciadopitys is the permineralized state of a Telemachus cone and should be treated as a junior synonym. Biotic interactions involving the reconstructed conifer genus include plant-insect interactions (oviposition by Odonata) and not less than five different types of plant-fungal interactions, including two distinct endomycorrhizal associations, two probable seed parasites, and epiphyllous fungi. A representative whole plant is reconstructed as a 10-15-m-tall, seasonally deciduous forest tree with a vertical, narrow-conical crown shape. We interpret these Telemachus trees as the dominant components of peat-forming conifer swamps, forest bogs, and immature bottomland vegetation in the Triassic high-latitude river basins of southern Gondwana. In architecture, growth habit, and many ecological characteristics, the Telemachus conifers appear to be comparable to extant larch (Larix). Owing to the large amount and often exquisite preservation of the material, this conceptual whole-plant genus represents one of the most completely reconstructed ancient conifer taxa to date.
\end{abstract}

Keywords: Triassic, Antarctica, conifer, whole-plant reconstruction, Heidiphyllum, Telemachus, Notophytum.

\section{Introduction}

The reassembly of isolated parts of fossil plants into whole-plant reconstructions has been one of the major goals of paleobotany in a biological perspective since the early days of the discipline (Unger 1847; Grand'Eury 1877; Oliver and Scott 1904). Whole-plant reconstructions play an important role for placing and interpreting extinct plants in a variety of scientific contexts, including physiological and ecological as well as systematic and evolutionary studies (Dilcher 1991; Stewart and Rothwell 1993; DiMichele and Gastaldo 2008; Bateman and Hilton 2009; Taylor et al. 2009; Dunn et al. 2012). The methods that can be used to reconstruct fossil plants from individual isolated body parts or organs can be classified into three main approaches: (1) identifying organic connections, (2) determining morphological similarities/structural correspondences, and (3) analyzing association/disassociation data (Bateman and Rothwell 1990; Bateman and Hilton 2009). Particular lines of evidence in these categories are diverse; they

${ }^{1}$ Author for correspondence; e-mail: bbomfleur@ku.edu. can be based, for instance, on cuticle micromorphology and epidermal anatomy (Harris 1956; Kerp 1990), on in situ and ex situ palynology (Kvaček 2008), or on the identification of one plant organ in different preservational states (Chaloner 1986; Galtier 1986). In addition, integrating information on abiotic parameters (derived from, e.g., taphonomical, sedimentological, or geochemical data) and biological interactions (e.g., fungal associations, plant-arthropod interactions) can make it possible to appreciate a fossil plant as an ecological entity, with a network of biotic interrelationships and specific environmental settings (DiMichele and Gastaldo 2008).

We here propose the first conceptual whole-plant reconstruction for a genus of Triassic voltzialean conifers from Antarctica, on the basis of a synthesis and reinterpretation of previously published data and on additional information gathered from newly collected material. The reconstruction is founded on a combination of different lines of evidence, including (1) organic connections, (2) structural correspondences between compressed and permineralized organs, (3) similarities in cuticle morphology and epidermal anatomy, (4) association/disassociation data, and (5) ex situ palynology. Moreover, there is evidence for not less than six different 

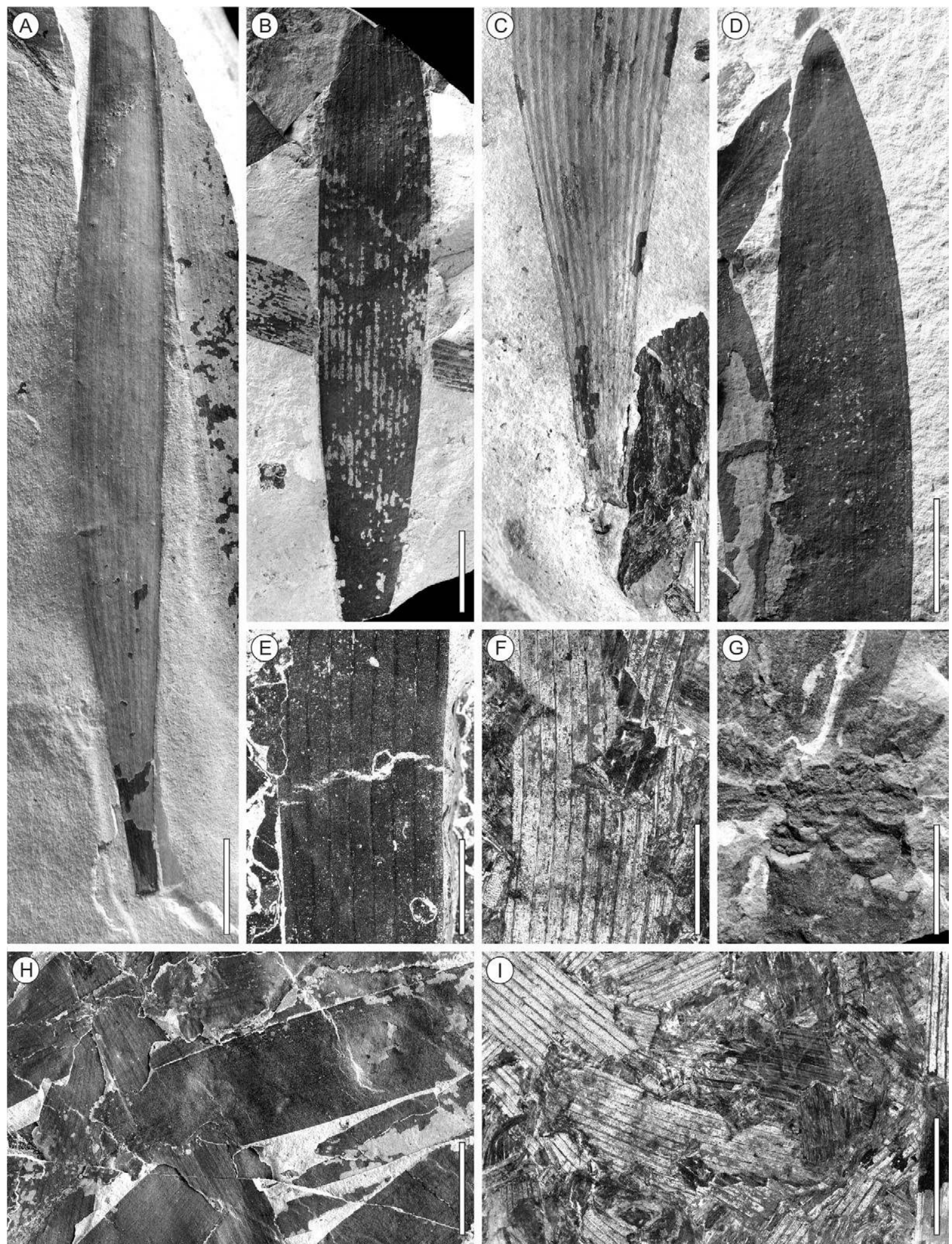

Fig. 1 Morphology of voltzialean leaves from the Triassic of Antarctica. A, General view of a leaf compression (Heidiphyllum elongatum) showing the strap-shaped outline, apetiolate base, and parallel venation. Specimen T11-654 from Allan Hills. Scale bar $=1 \mathrm{~cm}$. $B$, Central portion of a leaf compression (H. elongatum) showing parallel venation. Specimen T582 from Allan Hills. Scale bar $=1 \mathrm{~cm}$. C, Base of a leaf compression $(H$. elongatum). Specimen T206a from Allan Hills. Scale bar $=5 \mathrm{~mm}$. D, Apex of a leaf compression (H. elongatum). Specimen T11-652 from Allan Hills. Scale bar $=1 \mathrm{~cm}$. E, Detail of parallel venation in a leaf compression (H. elongatum) from the Alfie's Elbow locality. Specimen T5570. Scale bar $=$ $5 \mathrm{~mm}$. F, Detail of parallel venation in a permineralized leaf (Notophytum krauselii) preserved on the surface of a permineralized peat block from 
types of biotic interactions, including associations with various forms of fungi as well as odonatan insects.

In order to take into account that this reconstruction may include possibly more than nine individual natural species with overall similar anatomical, morphological, and ecological characteristics, we propose a reconstruction at the genus level. As such, our approach can be considered similar to that of Crane (1984) for his reconstruction of the Nyssidium plant. Owing to the large amount and often exquisite preservation of the material, this conceptual whole-plant genus represents one of the most completely reconstructed ancient conifer taxa to date.

This work is organized in two main parts. First, we provide a brief review of Antarctic voltzialean taxa on the basis of previous work and new observations. We (1) synthesize the main morphological and anatomical characteristics of the detached conifer organs preserved as compressions and permineralizations in the Triassic of Antarctica; (2) list all evidence for affiliation of these taxa based on organic connections, structural similarities, cuticle and epidermal similarities, co-occurrences, and ex situ palynology; and (3) review the information on biotic interactions documented for different organs. We then use these data as a basis to establish a whole-plant concept at the genus level for the Triassic voltzialean conifers of Antarctica and discuss nomenclatural and taxonomic aspects as well as the paleoecology of these plants and of the paleoenvironment in which they grew.

\section{Material and Methods}

This study is based on material housed in the paleobotanical collections of the Natural History Museum and Biodiversity Institute, University of Kansas (Lawrence, Kansas). The studied plant fossils consist of compression/impression specimens and permineralizations that were collected during repeated field trips to Antarctica since the 1980s. Voltzialean compression/ impression fossils have previously been collected from the Upper Triassic Falla Formation at Alfie's Elbow and Mount Falla (Central Transantarctic Mountains) and from the Upper Triassic members C and D of the Lashly Formation at Allan Hills and Shapeless Mountain (south Victoria Land); permineralized voltzialean remains were collected from permineralized peat deposits of the uppermost (Middle Triassic) part of the Fremouw Formation at Fremouw Peak and from a Middle or Upper Triassic deposit at the base of Mount Falla (both Central Transantarctic Mountains). Most of this material has been prepared, studied, and published previously; detailed information on individual sites and preparation techniques can be found in the relevant original publications as referred to in the text. A geographic and stratigraphic overview of the localities is provided by Escapa et al. (2011).

In addition to the reinvestigation of this material, this study includes the description of new specimens that have recently become available from two sites discovered in the
Queen Alexandra Range, Central Transantarctic Mountains, during the austral summer 2010-2011. A new site with permineralized peat and wood occurs in Gordon Valley in vicinity to the in situ forest described by Cúneo et al. (2003). In addition, a new compression assemblage with abundant voltzialean leaves and cones was sampled from a yet undetermined stratigraphic level in the Upper Triassic Falla Formation at Mount Falla, Queen Alexandra Range. In total, the material available in the collections consists of more than 2000 voltzialean compression fossils and more than 3000 blocks of silicified peat containing anatomically preserved voltzialean remains. New cellulose acetate peels (Galtier and Phillips 1999) were prepared for this study from small fragments of the silicified peat block 10,075 from Fremouw Peak, which contains well-preserved young stems and leaves of Notophytum. The blocks were etched for $\sim 2 \mathrm{~min}$ in $50 \%$ hydrofluoric acid. Selected portions of the peels were cut out and mounted on microscope slides using Eukitt solution (Kindler, Freiburg) for microscopic observation and photography. These seven new slides are deposited in the University of Kansas paleobotanical collections under the accession numbers 24,606-609 and 26,838840. All the other slides figured in this article are the original slides made by B. Meyer-Berthaud, X. Yao, and I. H. Escapa (Meyer-Berthaud and Taylor 1991; Yao et al. 1997; Escapa et al. 2010).

Hand specimens were photographed with a Nikon D300s digital single-lens reflex camera. Details were taken with a Leica DC500 digital camera attached to a Leica MZ 16 stereo dissecting microscope and to a Leica DM5000 compound microscope, respectively.

\section{Voltzialean Organs from the Triassic of Antarctica}

Voltzialean conifers are represented in the Triassic of Antarctica by several organs preserved in the form of compressions/ impressions, permineralizations, or both. Compression/impression organs include foliage, short shoots, seed cones, and pollen cones (figs. 1, 2); permineralized organs include axes (trunks, branches, young shoots, roots), foliage, seed cones, and pollen cones (figs. 3-6). We here provide a brief review of the main morphological and anatomical characteristics of the various detached organs described for the group from Antarctica to date.

\section{Stems and Roots (Figs. 3, 4A-4C, 4K)}

Notophytum krauselii Meyer-Berthaud and Taylor 1991. Anatomically preserved conifer stems and roots assigned to the monospecific genus Notophytum are abundant in Middle Triassic permineralized peat from Fremouw Peak (Meyer-Berthaud and Taylor 1991) and Gordon Valley (this study), in the Central Transantarctic Mountains. Notophytum represents the only axis type with well-established conifer affinities documented at these localities. Its size ranges from only a few millimeters wide in young stems and roots to large stems exceeding $20 \mathrm{~cm}$ in diam-

Fremouw Peak. Specimen 10,075. Scale bar $=5 \mathrm{~mm}$. G, Short shoot from Mount Falla bearing Heidiphyllum leaves and spirally arranged leaf scars. Specimen T5-48. Scale bar $=1 \mathrm{~cm} . H$, Mat of leaf compressions $(H$. elongatum) from Allan Hills. Specimen T8-275b. Scale bar $=1 \mathrm{~cm} . I$, Mat of anatomically preserved leaves $(N$. krauselii) on the surface of a block of permineralized peat from Fremouw Peak. Specimen 10,075 . Scale bar $=1 \mathrm{~cm}$. 

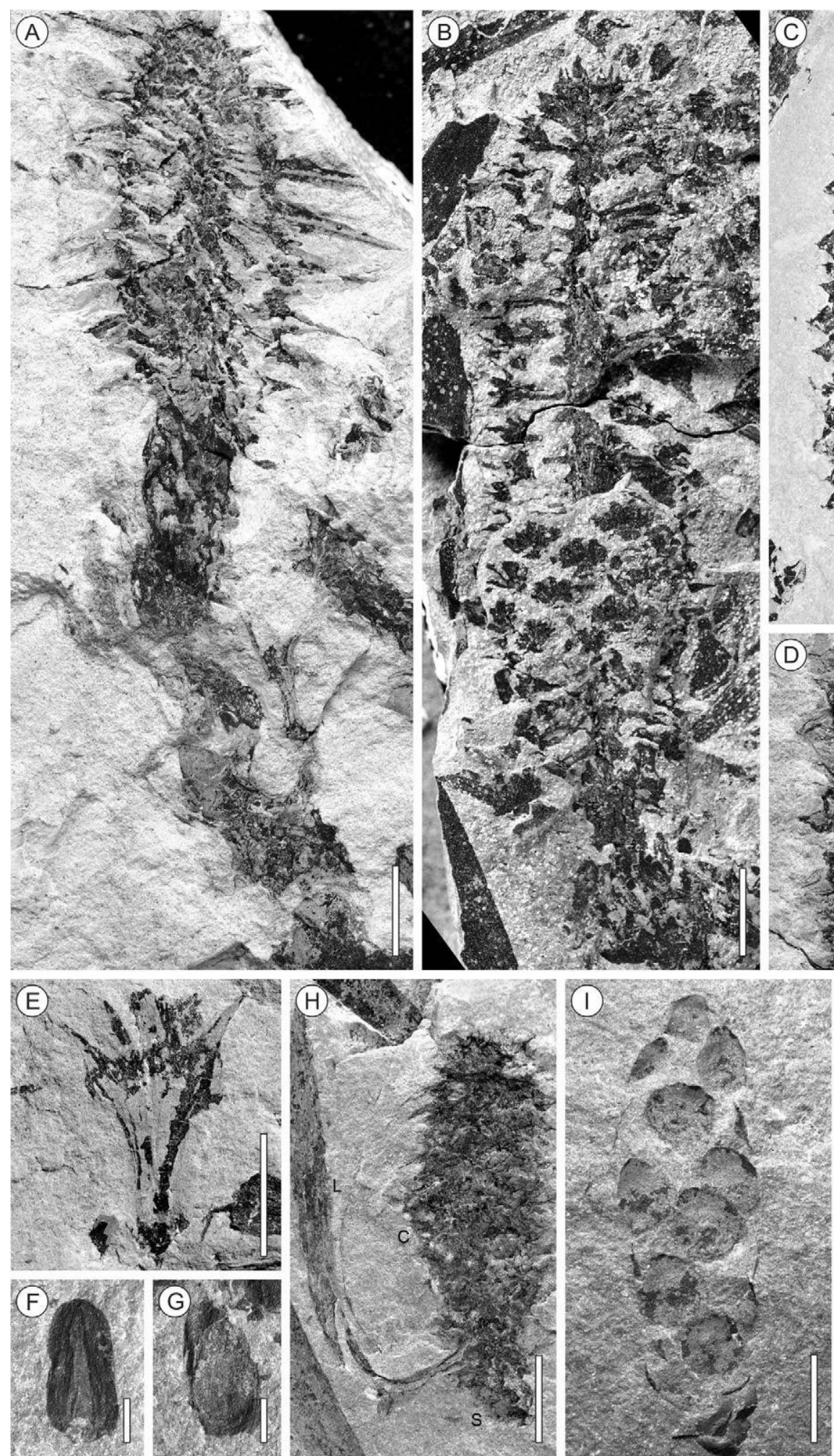
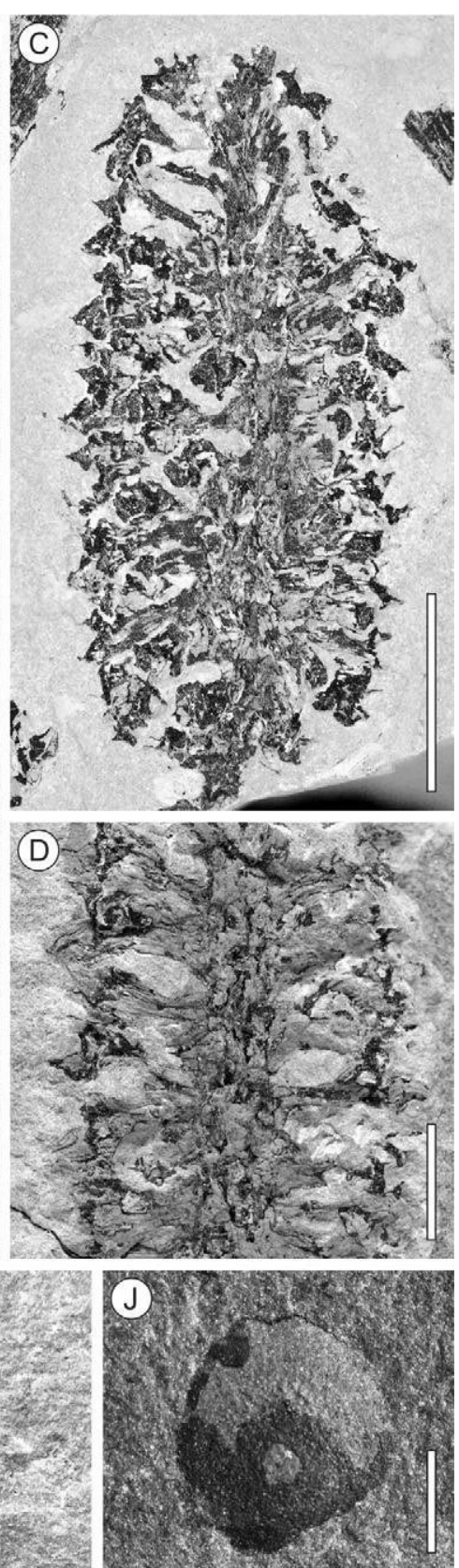

(K)

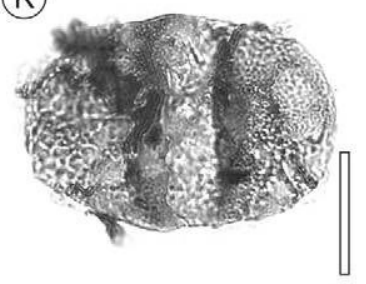

Fig. 2 Morphology of compression material of voltzialean seed cones (Telemachus; $A-E, H)$, dispersed seeds $(A-H)$, pollen cones (Switzianthus; I, J), and associated pollen $(K)$ from the Triassic of Antarctica. A, Ovuliferous cone (Telemachus elongatus) from Allan Hills showing terminal attachment and modified, triangular scale leaves. Specimen T202a. Scale bar $=1 \mathrm{~cm}$. B, Ovuliferous cone (Telemachus antarcticus) from Mount Falla showing different aspects of outer surface view (bottom) and cross section (top). Specimen T6495a+b. Scale bar $=$ $1 \mathrm{~cm}$. C, Ovuliferous cone (T. antarcticus) from Allan Hills. Specimen T11-411. Scale bar $=1 \mathrm{~cm} . D$, Detail of an ovuliferous cone (T. antarcticus) from Allan Hills. Specimen T11-355a + b. Scale bar $=5 \mathrm{~mm}$. E, Detached ovuliferous scale complex of T. antarcticus from Allan Hills. Specimen 

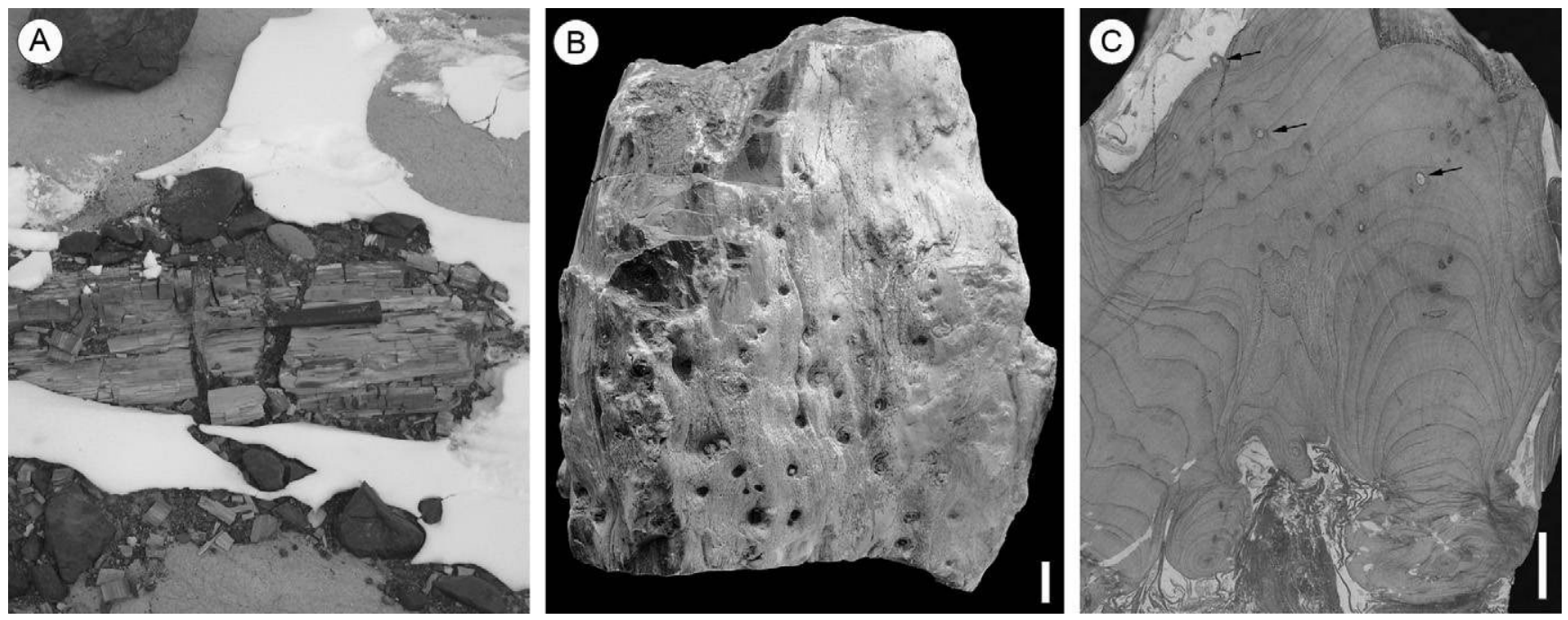

Fig. 3 General aspect of voltzialean trunks and roots (Notophytum) from the Triassic of Antarctica. A, Permineralized trunk at Fremouw Peak. B, Large piece of wood from Gordon Valley with numerous scars of sucker shoots. Scale bar $=1 \mathrm{~cm}$. C, Transverse section of a group of large roots showing numerous vascular traces to sucker shoots recognizable by their conspicuous pith. Specimen $10,730 \mathrm{~B}$. Scale bar $=1 \mathrm{~cm}$.

eter (figs. $3 A, 3 B, 4 A$ ). Branching of stems is axillary and occurs at wide angles approaching $90^{\circ}$. It is irregularly helical and alternates between widely spaced and contracted to form characteristic successions of pseudowhorls (Meyer-Berthaud and Taylor 1991). The stems have a parenchymatous pith (fig. $4 A, 4 B$ ) containing axial rows of cells with a dark content. The primary xylem forms eight to 13 sympodia with endarch maturation (fig. $4 A, 4 B$ ). In some of the young stems, the cortex is preserved, showing the phyllotaxis and anatomy of leaf bases (fig. $4 A, 4 E$ ). Leaf traces diverge tangentially from an axial bundle and divide in the cortex into four to six bundles. The phyllotaxy follows either a single or two opposite (i.e., bijugate), tight spirals. The secondary xylem shows distinct growth rings with a small amount of latewood. Rays are low and uniseriate in tangential section. The tracheids have a mixed radial pitting (fig. 4C). Cross-field pitting consists of usually one or two, rarely four, large pits with little or no border (fig. 4C). Secondary phloem is composed of alternating bands of sieve cells and parenchyma; bands of fibers are also present in some stems. Some large specimens show a thick bark, occasionally up to almost $1 \mathrm{~cm}$ wide in section. The tissues are arranged in concentric rings around the stem, suggesting that the outer aspect of the bark was rather smooth (ringbark) than scaly (Esau 1965, p. 347; this study).

The roots, initially described by Millay et al. (1987) as belonging to Antarcticoxylon, show the same wood anatomy as the stems (Meyer-Berthaud and Taylor 1991). The perminer- alized peat blocks from Fremouw Peak contain large, up to several-centimeter-wide roots with secondary growth (fig. $3 C$ ) as well as very young roots of only $\sim 0.5 \mathrm{~mm}$ width. In some cases, these young roots have been shown to contain phi thickenings (Millay et al. 1987). Furthermore, some of the young roots bear small lateral nodules similar to the mycorrhizal nodules produced by some extant conifers (fig. 6H-6J; Schwendemann et al. 2011; see also "Plant-Fungal Interactions (Figs. 6C-6J, 7)"). Larger roots occasionally show evidence of the production of root suckers (figs. $3 C, 4 K$ ) in the form of groups of very young, emerging stems with attached leaves (Decombeix et al. 2011).

Occurrences outside Antarctica: unknown. Meyer-Berthaud and Taylor (1992), however, noted that decorticated stems of Notophytum fit in the diagnosis of the morphogenus Megaporoxylon Kräusel, a taxon that has been reported from several primarily Paleozoic localities throughout Gondwana (Maheswari 1972; Prasad 1982, and references therein). While the affinities of Megaporoxylon are almost impossible to establish with certainty, this raises the question as to whether decorticated Notophytum stems from outside of Antarctica might have been described under this name.

$$
\text { Foliage (Figs. 1, 4D-4J) }
$$

Heidiphyllum elongatum (Morris) Retallack 1981. Compression/impression foliage of this widespread morphospecies is documented from several Antarctic locali-

T11-411b. Scale bar $=5 \mathrm{~mm} . \mathrm{F}, \mathrm{G}$, Two dispersed Telemachus seeds from Mount Falla. Both on specimen T5-169a. Scale bars $=2 \mathrm{~mm}$. H, Compact, presumably immature ovuliferous cone (C; T. elongatus) attached to a shoot (S) bearing Heidiphyllum leaves (L). Specimen T6450a. Scale bar $=1 \mathrm{~cm}$. I, Pollen cone compression (Switzianthus sp.) from Mount Falla. Specimen T7-185a. Scale bar = $5 \mathrm{~mm}$. J, Detail of a detached microsporophyll of Switzianthus sp. showing pedicel scar and surrounding rugose area interpreted as the area of former pollen sac attachment. Specimen T7-175b from Mount Falla. Scale bar $=2 \mathrm{~mm}$. K, Bisaccate pollen grain extracted from a Switzianthus cone from Mount Falla. Slide 24,026. Scale bar $=25 \mu \mathrm{m}$. 


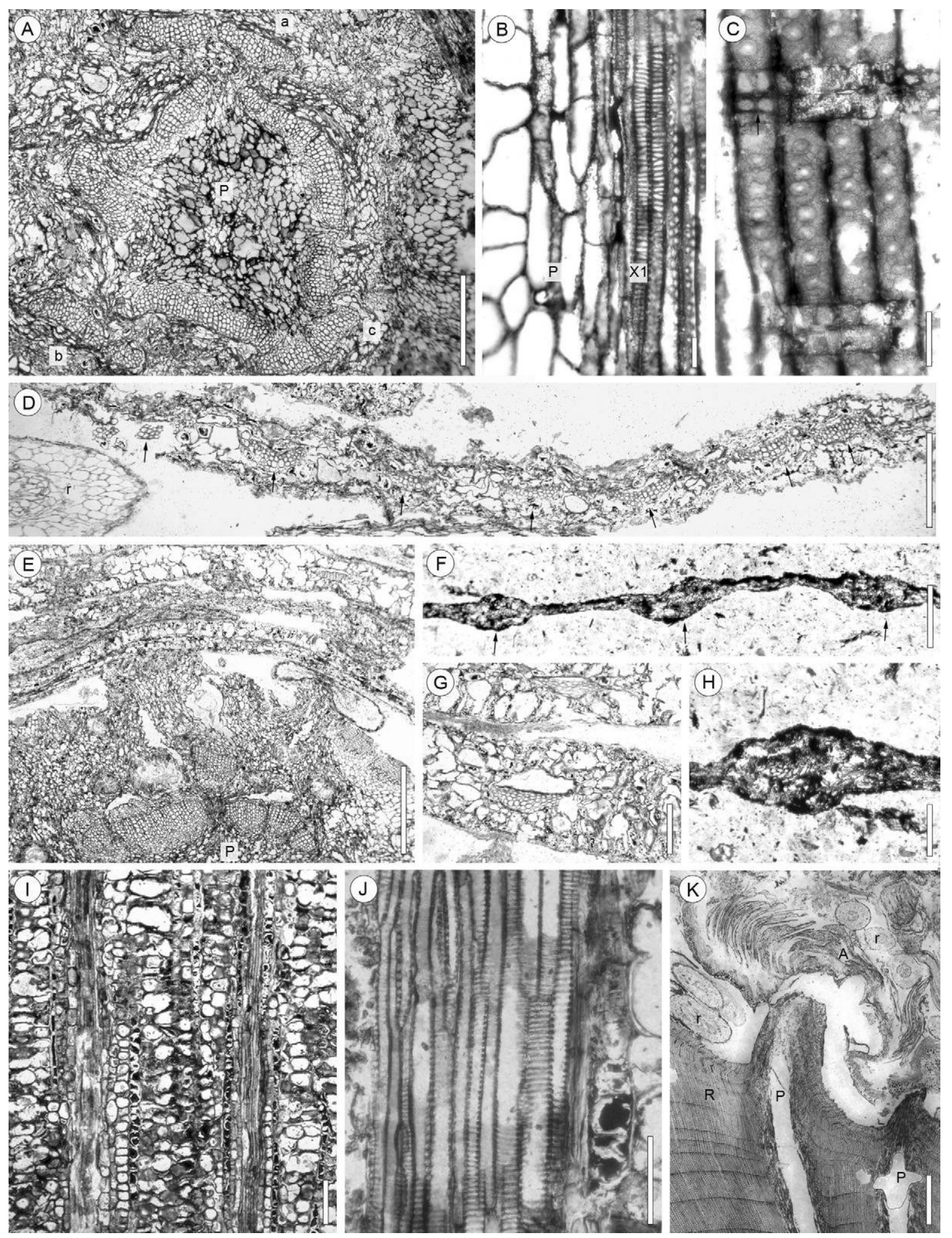

Fig. 4 Anatomy of voltzialean stems and leaves from the Triassic of Antarctica. A, Cross section of young stem (Notophytum) from Fremouw Peak showing the parenchymatous pith $(\mathrm{P})$, a small amount of wood, and three departing leaf traces $(\mathrm{a}-\mathrm{c})$ emitted in compact spiral. Specimen 10,075E (slide 24,606). Scale bar $=500 \mu \mathrm{m}$. B, Radial section of a stem (Notophytum) from Fremouw Peak showing the anatomy of pith $(\mathrm{P})$ and endarch primary xylem (X1). Specimen 10,145G. Scale bar $=50 \mu \mathrm{m}$. C, Radial section in the secondary xylem of an older stem from Fremouw Peak (Notophytum) showing the radial pitting and typical cross-field pitting consisting of two pits per cross-field (arrow). Specimen 10,246C. Scale bar $=50 \mu \mathrm{m} . D$, Cross section through a leaf from Fremouw Peak (Notophytum) with at least seven vascular bundles (arrows). Note part of 
ties, including (1) the Upper Triassic localities of Alfie's Elbow and Mt. Falla in the Central Transantarctic Mountains; (2) the Middle and Upper Triassic localities of Portal Mountain, several sites in the Allan Hills, Mount Bastion, and Shapeless Mountain in South Victoria Land; and (3) the Upper Triassic localities of Timber Peak and Vulcan Hills in North Victoria Land (Escapa et al. 2011). The Antarctic Heidiphyllum leaves are up to $\sim 25 \mathrm{~cm}$ long, strap-shaped to narrow-elliptic, apetiolate, evenly tapering toward the base, and have an obtusely rounded to subacute apex (fig. $1 A-1 D$ ). Their venation consists of usually $8-12$ parallel veins that are produced immediately above the leaf base through repeated dichotomies of the basal veins (figs. $1 A-1 E, 4 F$ ). The number of veins entering the leaf base is not clearly discernible; the characteristically crescent-shaped leaf scars on a Heidiphyllumbearing short shoot from Mount Falla (fig. 1G), however, show a pair of two lateral bundle scars. A further important diagnostic feature of Heidiphyllum is the presence of interveinal striae (Anderson and Anderson 1989).

A compressed leaf occurring in the same block as one of the Telemachus specimens described by Escapa et al. (2010) and tentatively assigned to Heidiphyllum shows some preservation of the vascular tissues (this study; fig. 4F, 4H). The leaf fragment contains at least five preserved parallel bundles with crescent-shaped primary xylem strands.

Cuticles of Heidiphyllum appear to have been very thin and membranaceous and are rarely preserved, even in deposits that contain abundant and well-preserved cuticles of other gymnosperms (Retallack 1977; Anderson 1978; Axsmith et al. 1998). Despite the thicker leaf substance, in this aspect the preservation of Heidiphyllum leaves appears more closely comparable to that of co-occurring fern foliage than to that of associated other gymnosperms, that is, Corystospermales and Peltaspermales (Bomfleur and Kerp 2010; Bomfleur et al. 2011b). We reinvestigated the cuticles described by Axsmith et al. (1998) as belonging to Heidiphyllum elongatum and found that the cuticle pieces were in fact extracted from a small fragment of a Dejerseya leaf (Bomfleur et al. $2011 b$ for comparisons). To our knowledge, the only reliable account on cuticle features of Heidiphyllum therefore remains that of Anderson (1978; see also Retallack 1981; Anderson and Anderson 1989, 2003). The lower epidermis is characteristically papillate; the stomatal pores are irregularly oriented and surrounded by a ring of five or six thickened subsidiary cells with papillae that do not overarch the pit.

Heidiphyllum commonly occurs in dense mats of complete, individually abscised leaves (fig. 1H; Anderson 1978; Retallack 1981; Anderson and Anderson 1989), which has been interpreted as evidence for seasonal leaf abscission (as opposed to shoot abscission; Harris 1976; Axsmith et al. 1998). Considering the wide distribution and overall abundance of Heidiphyllum foliage, the few finds of attached leaves (Anderson and Anderson 2003; this study; fig. 1G) can therefore be regarded as exceptionally rare. These specimens demonstrate that Heidiphyllum leaves were borne spirally on short shoots. A short shoot with an attached basal portion of a Heidiphyllum leaf from Mount Falla furthermore shows prominent, crescent-shaped leaf scars, each with a lateral pair of bundle scars (this study; fig. 1G). The densely disposed leaf scars on this specimen measure up to $\sim 2 \mathrm{~mm}$ high by up to $\sim 4 \mathrm{~mm}$ wide.

Occurrences outside Antarctica: South Africa (Anderson 1978; Anderson and Anderson 2003), New Zealand (Retallack 1981), South America (Artabe et al. 2001), Australia, and India (see Anderson and Anderson 2003).

Notophytum krauselii Meyer-Berthaud and Taylor 1991. Permineralized leaves found in connection with Notophytum krauselii axes from Fremouw Peak are elongate with 8-12 parallel veins (figs. 1F, 1I, 4D; Meyer-Berthaud and Taylor 1991; Axsmith et al. 1998). The leaf base is wider than high, up to $2 \mathrm{~mm} \times 0.5 \mathrm{~mm}$. There is no distinct petiole. No leaf apex has been found, but some well-preserved specimens show no evidence of tapering over several centimeters, which led Axsmith et al. (1998) to suggest that the leaves must have by far exceeded the preserved length of $3 \mathrm{~cm}$. Vascular bundles (fig. 4D, 4G, 4I, 4J) are subtended by a resin canal and flanked by strands of transfusion tracheids. Palisade cells are usually filled with a dark substance. The mesophyll contains obliquely oriented cells with thick walls interpreted as sclereids. The abaxial epidermis is papillate. Stomata are sunken. Some peat blocks from Fremouw Peak and from the nearby Gordon Valley (this study) are almost exclusively composed of mats of these leaves (figs. 1I, 4E), which, combined with the anatomical evidence for short life span, has been interpreted as evidence that Notophytum leaves were also shed seasonally.

Occurrences outside Antarctica: Unknown, but see "Leaves, Stems, and Roots of Notophytum."

\section{Seed Cones (Figs. 2A-2H, 5, 6D)}

Telemachus Anderson Emend. Escapa, Decombeix, Taylor \& Taylor 2010. Telemachus was erected for seed cones preserved as compressions/impressions from the Triassic of South Africa (Anderson 1978). Eight species were subsequently described throughout Gondwana, and two are documented in Antarctica, that is, the type species Telemachus

a young root (Notophytum) on the left (r). Specimen 10,075E (slide 24,607). Scale bar $=250 \mu \mathrm{m}$. E, Cross section through part of a young stem (bottom) and leaf mat (top) from Fremouw Peak (Notophytum). Specimen 10,075E (slide 24,607). Scale bar $=500 \mu \mathrm{m}$. F, Cross section of part of a leaf compression (Heidiphyllum?) from the Alfie's Elbow locality. The vascular bundles (arrows) are the only preserved part. Specimen T-5594. Scale bar $=250 \mu \mathrm{m}$. G, Detail of two leaves (Notophytum) from Fremouw Peak in cross section showing the vascular bundles (phloem is not preserved) and the general leaf anatomy. Specimen 10,075E (slide 24,608). Scale bar $=100 \mu \mathrm{m}$. $H$, Detail of the same leaf as in $F$ showing a vascular bundle. Specimen T-5594. Scale bar $=100 \mu \mathrm{m}$. I, Longitudinal section of a leaf from Fremouw Peak (Notophytum) showing detail of two parallel veins and rows of dark cells flanking the bundles. Specimen 10,075E (slide 26,838). Scale bar $=100 \mu$ m. $J$, Detail of a leaf vascular bundle (Notophytum) in longitudinal section. Specimen 10,075E (slide 26,838). Scale bar $=50 \mu \mathrm{m}$. K, Transverse section of the outer part of a large Notophytum root (R) showing the vascular traces to two young sucker shoots characterized by their parenchymatous pith (P). Note the preserved leafy bud at the apex of the left sucker shoot $(\mathrm{A})$ and young roots in the matrix $(\mathrm{r})$. Specimen $11,160 \mathrm{C}$. Scale bar $=1 \mathrm{~mm}$. 

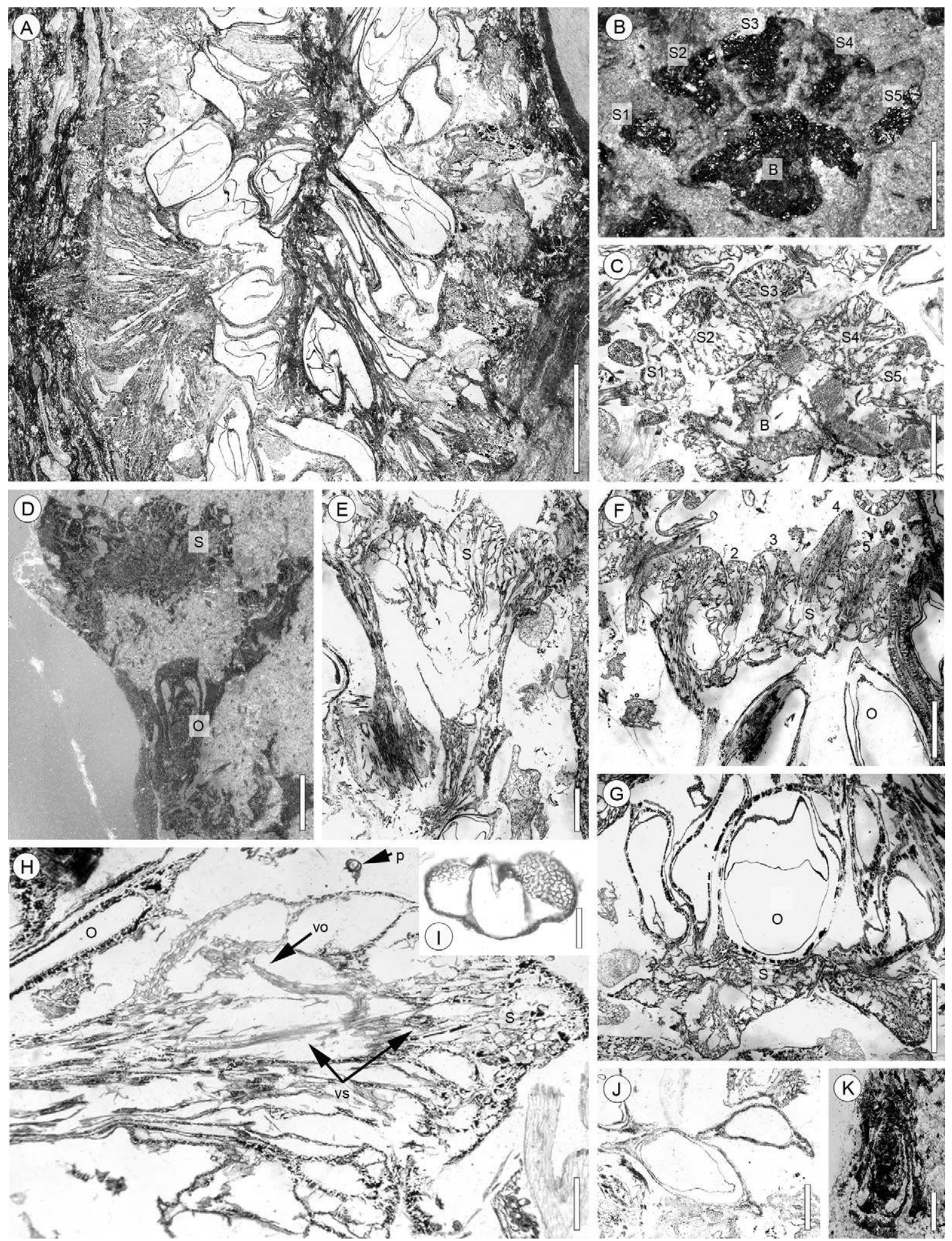

Fig. 5 Anatomy of voltzialean seed cones: Telemachus (B, D, K), Parasciadopitys aequata (=Telemachus aequatus comb. nov.; see appendix; $A, C, E-J)$, and associated pollen $(I)$ from the Triassic of Antarctica. A, Longitudinal section through a permineralized seed cone from Fremouw Peak (Parasciadopitys) showing the ovuliferous complexes arranged around the woody axis. Specimen $15156 \mathrm{E}$. Scale bar $=2.5 \mathrm{~mm}$. B, Transverse section (i.e., tangential section of the cone) through an ovuliferous complex of a compressed seed cone from Allan Hills (Telemachus antarcticus) showing the bract (B) and five tips of the scale (S1-S5). Specimen T11-409. Scale bar $=1 \mathrm{~mm}$. C, Transverse section through an ovuliferous complex of a permineralized seed cone from Fremouw Peak (P. aequata) showing the bract (B) and five tips of the scale (S1-S5). Slide 19,571. 
elongatus and Telemachus antarcticus (Yao et al. 1997; Escapa et al. 2010). All the Antarctic specimens are Late Triassic in age. Both species occur in the Allan Hills (South Victoria Land), while only T. elongatus is documented in the Central Transantarctic Mountains localities of Mount Falla and Alfie's Elbow. Some of the cones, although compressed, show some anatomical details (Escapa et al. 2010). The cones are up to $6 \mathrm{~cm}$ long and $64 \mathrm{~cm}$ wide for T. elongatus and up to $4 \mathrm{~cm}$ long and $\sim 2 \mathrm{~cm}$ wide for $T$. antarcticus. Both species are characterized by helically arranged ovulate complexes on a thick woody axis (fig. $2 A-2 D$ ). Bract and ovuliferous scale are fused for half their length (fig. $2 D)$. The apex of the ovuliferous scale is divided into five tips (figs. $2 E$, $5 B$ ). The vascular trace is single at the base of the ovulate complex and then divides to form one strand in the bract and five in the scale. One of the most conspicuous differences between the two Antarctic species is the length of their bract, which is more than $15 \mathrm{~mm}$ in T. elongatus versus $3 \mathrm{~mm}$ maximum in $T$. antarcticus (fig. $2 A, 2 C$ ). There is no evidence that $T$. antarcticus represents a different ontogenetic stage of T. elongatus, for which both mature and immature specimens are found in the Antarctic material (Escapa et al. 2010).

Ovules are well preserved on some of the specimens. Although only up to three ovules have been indisputably observed in T. elongatus specimens, their original or potential maximum number is thought to be five per ovuliferous scale, since anatomical studies have shown that each lobe is vascularized individually (Escapa et al. 2010). Ovules of T. elongatus are oval in longitudinal section and at least $1.3 \mathrm{~mm} \times 0.3 \mathrm{~mm}$ (fig. $5 D$, $5 K$ ). Their nucellus is attached only at the chalazal end (fig. $5 K)$. In T. antarcticus, the rounded structures interpreted as representing the location of the ovules are 1.0-1.8 mm.

Dispersed seeds of Telemachus cones are particularly abundant in the compression flora from Mount Falla. The seeds are rounded rectangular, oblong elliptic, or ovate in outline and typically 6-6.5 mm long and 3-4 mm wide (fig. 2F, 2G). The integument encases a flattened-ovoidal to pyriform nucellus in the center (fig. 2G) and forms two opposite, narrow wings flanking the lateral and distal portion of the seed (fig. $2 F, 2 G$ ).

Specimens from Allan Hills and from Mount Falla show the terminal attachment of Telemachus cones. In most cases, the cones are borne on long shoots that bear small, triangular, scale-like adpressed modified leaves (fig. 2A). A single new specimen from Mount Falla, however, appears to be borne on a short shoot that also bears regular Heidiphyllum leaves (fig. $2 H$ ).

Occurrences of the genus outside Antarctica: Argentina (Morel 1994; Lutz 2006; Morel et al. 2011), Chile (Nielsen
2005), New Zealand (Retallack 1981), South Africa (Anderson 1978; Anderson and Anderson 2003).

Parasciadopitys aequata Yao Taylor and Taylor 1997. The genus Parasciadopitys, with the species Parasciadopitys aequata, was erected by Yao et al. (1997) for two Middle Triassic permineralized seed cones from Fremouw Peak in the Central Transantarctic Mountains. The few cones known so far are up to $3.4 \mathrm{~cm}$ long and $1.4 \mathrm{~cm}$ wide. Ovulate complexes are composed of a bract fused to the scale for one-fourth to three-fourths of its length and are arranged helically on a woody axis. Ovuliferous scales have five distal lobes at their tip (fig. $5 C, 5 F$ ). The vascular trace divides to form one strand in the bract and 5 in the scale. The bract is up to $8 \mathrm{~mm}$ long. Five inverted ovules are borne adaxially on each scale. The ovules are flattened and winged, up to $4.4 \mathrm{~mm}$ long, $3.2 \mathrm{~mm}$ in the primary plane and $2.1 \mathrm{~mm}$ in the secondary plane (fig. $5 F-5 H, 5 J$ ). The nucellus is attached only at the chalazal end. Abundant dispersed pollen grains occur around the ovuliferous scales inside the Parasciadopitys cones. These grains are bisaccate, measure $\sim 90 \mu \mathrm{m} \times$ $50 \mu \mathrm{m}$, and show coarse saccus reticulation (fig. 5I).

Cellularly preserved megagametophyte and embryo have been discovered within an isolated seed of $P$. aequata (fig. 6D; Schwendemann et al. 2010). The embryo measures $2.0 \mathrm{~mm}$ long and $530 \mu \mathrm{m}$ wide. The two cotyledons are $490 \mu \mathrm{m}$ long and $195 \mu \mathrm{m}$ wide, and the hypocotyl is $1.1 \mathrm{~mm}$ long and $530 \mu \mathrm{m}$ wide. Embryonic root cap measures $419 \mu \mathrm{m}$ in length and $414 \mu \mathrm{m}$ across. The embryo is surrounded by a mostly intact megagametophyte tissue; a small corrosion cavity occurs along a portion of the hypocotyl. Embryo cell dimensions are $\sim 18 \mu \mathrm{m} \times 24 \mu \mathrm{m}$, except in the region of the provascular tissue. Cells in the provascular region of the embryo are more elongate and typically reach lengths of $36 \mu \mathrm{m}$. Embryo cells have intercellular contents comprised of thin strands and spherical bodies of various sizes. Most notably, each cell of the embryo contains a single spherical body larger than the others $(\sim 5 \mu \mathrm{m}$ in diameter) interpreted as a preserved nucleus. In the region of the provascular tissue, these structures become more elongate and measure $\sim 3 \mu \mathrm{m} \times 18 \mu \mathrm{m}$. This phenomenon also occurs in nuclei in extant conifer embryos.

The fossil embryo exists in a relatively developed state; the two cotyledons are well developed, and provascular tissue can be seen extending from the tips of the cotyledons to the shoot apical meristem (fig. 6D). No secondary thickening patterns have been seen in any of the provascular tissue. The surface initials of the shoot apical meristem consists of a single layer of cells that undergoes anticlinal and periclinal divisions. The central mother-cell zone beneath these initials is comprised of approximately four layers. Both the transitional

Scale bar $=1 \mathrm{~mm} . \mathrm{D}$, Adaxial view (i.e., transverse section of the cone) of an ovuliferous complex of a compressed seed cone from Alfie's Elbow (Telemachus elongatus) showing the scale (S) divided at the tip and one inverted ovule (O). Specimen T-5594. Scale bar = 1 mm. E, Adaxial view of an ovuliferous complex of a permineralized seed cone from Fremouw Peak (P. aequata) showing the general aspect. Slide 19,528. Scale bar $=1 \mathrm{~mm}$. F, Adaxial view of another ovuliferous complex of a permineralized seed cone from Fremouw Peak (P. aequata) showing the scale (S) divided into five tips (1-5) and parts of two ovules (O). Slide 15,129. Scale bar $=1 \mathrm{~mm}$. G, Transverse section (i.e., tangential section of the cone) through an ovuliferous complex of a permineralized seed cone from Fremouw Peak (P. aequata) at the level of the ovules (O). Slide 15,537. Scale bar $=1 \mathrm{~mm}$. $H$, Tangential section (i.e., radial section of the cone) through an ovuliferous complex of a permineralized seed cone from Fremouw Peak (P. aequata) showing the vascularization of the scale tip (vs) and of an ovule (vo). Note the pollen grain (p). Slide 19,561. Scale bar $=$ $250 \mu \mathrm{m}$. I, Detail of a pollen grain found around the ovuliferous complexes of Parasciadopitys. Slide 19,550. Scale bar $=25 \mu \mathrm{m}$. $J$, Ovules of a permineralized seed cone from Fremouw Peak (P. aequata) in transverse section showing the flattened shape and two small wings. Slide $19,535$. Scale bar $=500 \mu \mathrm{m}$. K, Ovule of compressed seed cone from Alfie's Elbow (T. elongatus). Specimen T-5594. Scale bar $=500 \mu \mathrm{m}$. 

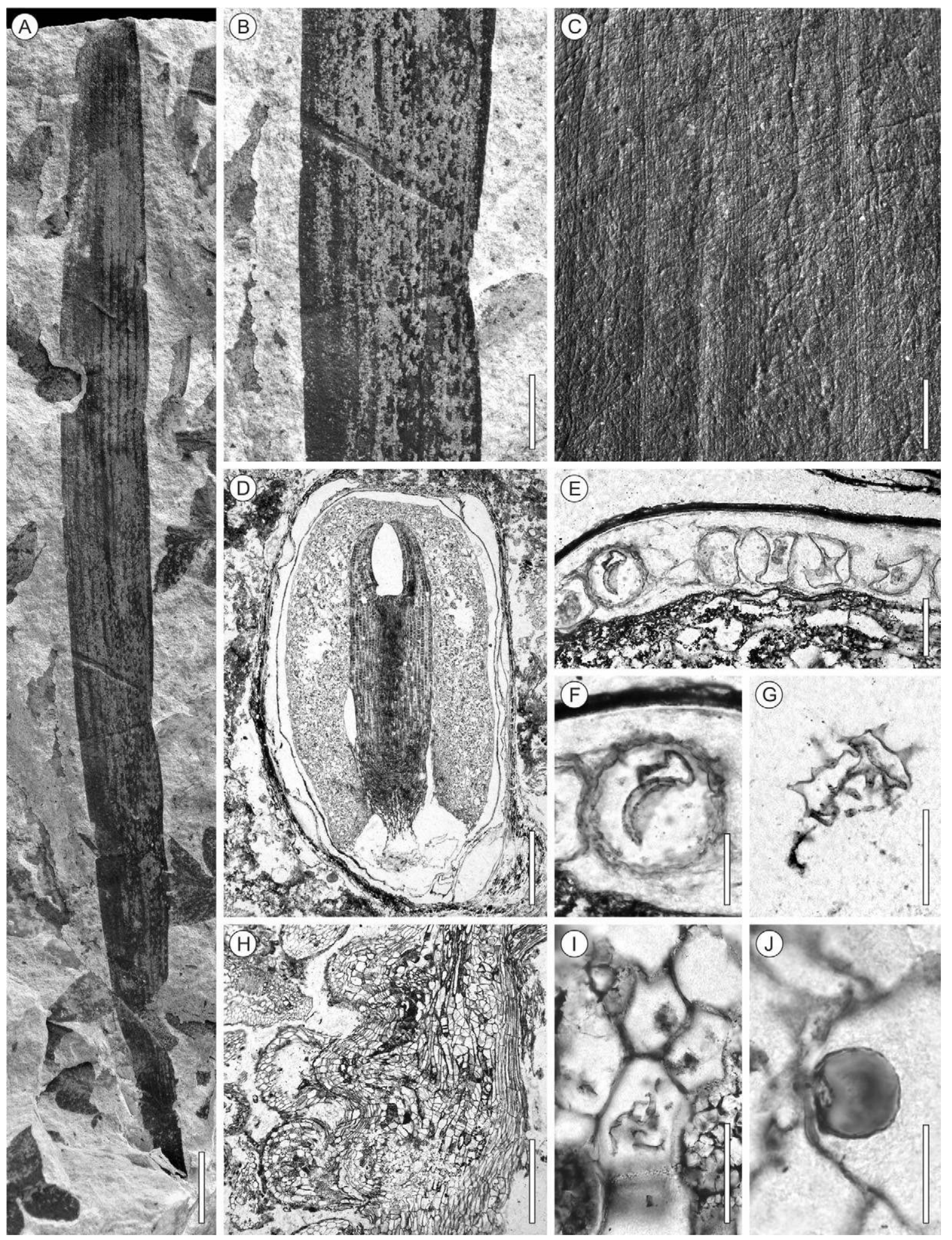

Fig. 6 Fossil evidence for biotic interactions involving the reconstructed Triassic Telemachus conifer from present-day Antarctica, including odonatan oviposition $(A, B)$ and a diverse suite of plant-fungal interactions $(C-J)$. A, Leaf compression (Heidiphyllum) with up to four parallel rows of insect egg traces in its basal portion. Specimen T1462b from Alfie's Elbow. Scale bar $=1 \mathrm{~cm}$. $B$, Detail of the same leaf in $A$, showing the regular linear arrangement and small size of the egg traces. Scale bar $=5 \mathrm{~mm}$. C, Close-up of a leaf compression (Heidiphyllum) showing a dense network of fungal hyphae. Specimen T11-583 from Allan Hills. Scale bar $=500 \mu \mathrm{m}$. D, Preserved embryo and megagametophyte tissue in a permineralized seed from Fremouw Peak (Parasciadopitys). Note the two cotyledons and shoot apical meristem of the embryo (top) and the 


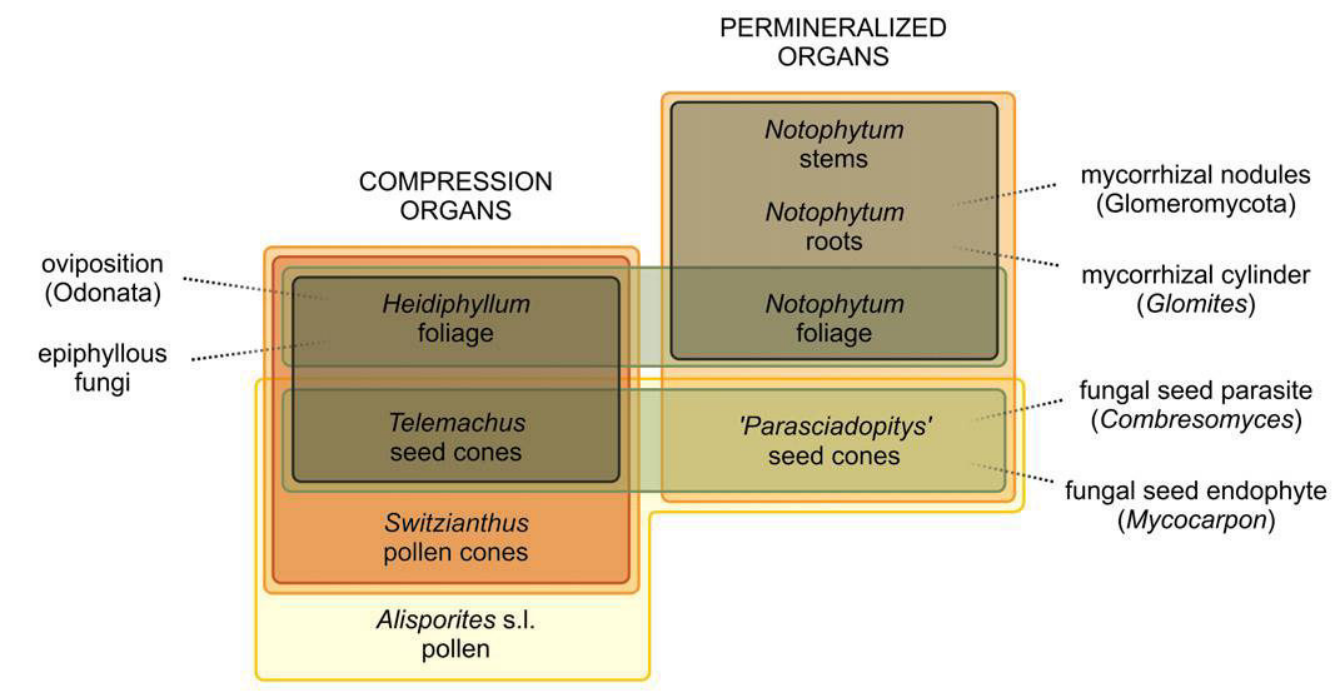

evidence for affiliation:

— $\begin{aligned} & \text { organic } \\ & \text { connection }\end{aligned}-\begin{aligned} & \text { structural } \\ & \text { correspondence }\end{aligned}-\begin{aligned} & \text { cuticle/epidermal } \\ & \text { similarities }\end{aligned} \quad$ - $\begin{aligned} & \text { association/ } \\ & \text { disassociation }\end{aligned}$ ex situ palynology

Fig. 7 Schematic diagram illustrating the accumulated evidence for the reconstruction of the Antarctic Telemachus conifer and associated biotic interactions. Note that two different subsets of affiliated organs-that is, one with affiliated compression taxa and the other with affiliated permineralizations - become tightly interconnected via the structural correspondence between the compressed and permineralized foliage and seed cones.

and peripheral zones are composed of only a few cells. Cells of the embryo differentiating into procambium tissue can be seen throughout the hypocotyl and in the area of the embryonic root cap. The embryonic root cap contains a meristematic layer and a developing root cap. A single group of cells is responsible for the production of all of the root tissue. The root apical meristem produces cells in an open organization; no junction zone exists between the hypocotyl and embryonic root. The entire embryo is surrounded by a single epidermal layer. Additionally, the remains of the suspensor have also been preserved, although there is no cellular detail.

Occurrences outside Antarctica: unknown.

\section{Pollen Cones (Fig. 2l-2K)}

Leastrobus fallae Hermsen Taylor and Taylor 2007. The monospecific genus Leastrobus has been established for two anatomically preserved pollen cones from Middle or Upper Triassic deposits at the base of Mount Falla in the Central Transantarctic Mountains. The incomplete cone fragments are up to $6 \mathrm{~mm}$ in height and $3.8 \mathrm{~mm}$ in width. The microsporophylls are arranged helically around a slender axis, and are subtended by bracts $\sim 3 \mathrm{~mm}$ in length. Microspo- rophylls are peltate, having a straight, slender pedicel and a distal laminar portion; the pollen sacs are attached adaxially-that is, on the inner surface of the lamina-and oriented parallel to the pedicel. Resin canals are present.

Pollen of Leastrobus is small (42-73 $\mu \mathrm{m}$ in length) and bisaccate. Sacci appear slightly constricted where they attach to the corpus. Each grain has a well-defined, distal longitudinal aperture (sulcus) between the sacci. The corpus is relatively thick walled and finely reticulate. The pollen type has been shown to correspond closely to the bisaccate pollen of some Northern Hemisphere Voltziales that is generally identified as the dispersed Alisporites sensu lato pollen type (Hermsen et al. 2007; see Balme 1995).

Occurrences outside Antarctica: unknown.

Switzianthus Anderson and Anderson 2003. The pollen cone Switzianthus has only recently been described from Antarctica (Bomfleur et al. 2011a). Nine compression/impression specimens were reported from Upper Triassic deposits at Mount Falla (Central Transantarctic Mountains) and the Allan Hills (South Victoria Land). Although the material does not show sufficient detail to enable identification on specific level, it appears overall similar to Switzianthus crispiformis, one of the two species described from the type strata in South Africa

developing root cap (bottom). Specimen 10,160D. Scale bar $=500 \mu \mathrm{m}$. E, Detail of the same seed in D, showing sporocarps of an endophytic fungus (Mycocarpon asterineum) between the nucellus and megagametophyte. Specimen 10,160D. Scale bar $=50 \mu \mathrm{m}$. F, Higher magnification of a seed endophyte sporocarp (M. asterineum). Specimen 10,160D. Scale bar $=25 \mu \mathrm{m}$. G, Detail of the same seed in $D$, showing the oogonium of a probably parasitic fungus (Combresomyces cornifer) within an empty pocket of degraded megagametophyte tissue. Specimen 10,160D. Scale bar $=50 \mu \mathrm{m} . \mathrm{H}$, Mycorrhizal nodules on a longitudinal section of a young root (Notophytum). Specimen $16207 \mathrm{G}$. Scale bar $=500 \mu \mathrm{m}$. $I$, Probable arbuscule within a cell of a young root nodule. Specimen $16207 \mathrm{G}$. Scale bar $=50 \mu \mathrm{m}$. J, Spherical vesicle in the cortex of a root nodule. Specimen 11277 B. Scale bar $=25 \mu \mathrm{m}$. 
(Anderson and Anderson 2003). The cones are 2.7-4 cm long and $0.8-1.5 \mathrm{~cm}$ wide (fig. 2I). The microsporophylls are arranged helically, with six to 10 scales by helix. The microsporophylls are peltate, with a delicate pedicel and a distal, ovate laminar portion with an acute or obtusely rounded apex (fig. 2J). Pollen sacs have not been observed, but the area above the pedicel attachment on the inner sporophyll lamina bears characteristic surface markings that have been interpreted as indicating the area of pollen sac attachment (Anderson and Anderson 2003; Bomfleur et al. 2011a). Pollen grains recovered from Switzianthus cones are $\sim 60-100$ $\mu \mathrm{m}$ long $\times 38-60 \mu \mathrm{m}$ high, bisaccate nontaeniate, and show relatively coarse saccus reticulation and a prominent, distal longitudinal aperture (fig. 2K; Anderson and Anderson 2003; Bomfleur et al. 2011a).

Occurrences of the genus outside Antarctica: South Africa (Anderson and Anderson 2003).

\section{Associated Biotic Interactions}

\section{Plant-Animal Interactions (Figs. 6A, 6B, 7)}

Evidence for plant-animal interactions involving the Antarctic Triassic Telemachus conifers is extremely sparse. A detailed survey of the available material at the University of Kansas produced only a single trace of plant-animal interactions; the specimen is a Heidiphyllum leaf from Alfie's Elbow. The almost complete leaf contains more than 100 traces of insect eggs (fig. 6A, 6B) that are longitudinally aligned and densely disposed in up to at least four regular vertical rows parallel to veins and leaf margin. The traces are $\sim 1 \mathrm{~mm}$ long, ovate depressions in the leaf surface, each being usually surrounded by a more or less distinctive, thickened rim of reaction tissue. The small size of the egg traces, their large number and characteristic arrangement in parallel vertical rows, and the insertion into the lamina of a living leaf indicates that this oviposition trace was most likely produced by a member of the Odonata (van Konijnenburg-van Cittert and Schmeißner 1999; Vasilenko and Rasnitsyn 2007; Sarzetti et al. 2009). Whereas such traces have traditionally been referred to in open nomenclature (Grauvogel-Stamm and Kelber 1996; van Konijnenburg-van Cittert and Schmeißner 1999), several very different approaches for the systematic classification of insect damage structures on leaves have recently been proposed (Vasilenko 2005; Labandeira et al. 2007; Krassilov and Rasnitsyn 2008; Sarzetti et al. 2009). The material described appears most closely comparable to damage type DT100 of Labandeira et al. (2007) and the ichnospecies Paleoovoidus rectus of Vasilenko (2005), respectively.

\section{Plant-Fungal Interactions (Figs. 6C-6), 7)}

The voltzialean plant remains from the Fremouw Peak locality are associated with four distinct endobiotic microorganisms (Schwendemann et al. 2010, 2011; C. J. Harper, personal communication, 2012). The plant and the fungi are involved in both mutualistic and parasitic symbiotic relationships. Although the limited number of specimens makes it difficult to interpret these relationships in greater detail, there is enough evidence to make general suppositions about the interspecies interactions. In addition, we here present the first evidence for epiphyllous fungi on Heidiphyllum leaves on the basis of material from Allan Hills.

Mycorrhizal Associations. Two distinct types of mycorrhizal symbioses are known from the roots of the Telemachus plants. Some young Notophytum roots produced mycorrhizal root nodules (fig. 6H-6J; Schwendemann et al. 2011) that contain fungi involved in mutualistic symbiotic relationships with the plant. Among extant gymnosperms, mycorrhizal root nodules occur only in the Podocarpaceae, Araucariaceae, and Sciadopityaceae (Khan and Valder 1972). The cortices of these nodules are inhabited by arbuscular mycorrhizal fungi that are cut off from the rest of the plant (Russell et al. 2002). Evidence indicates that the plant receives phosphorus from the fungus (Morrison and English 1967). Moreover, very young Notophytum roots have recently also been shown to contain a regular mycorrhizal cylinder (C. J. Harper, personal communication, 2012). By analogy with extant mycorrhizal associations (Russell et al. 2002; Scheublin et al. 2004), it can be assumed that different fungal species were involved in these two distinct types of symbiotic interactions.

Seed Parasites. Two fungal microorganisms are present in a seed containing well-preserved embryo and megagametophyte tissues (fig. 6D-6G; Schwendemann et al. 2010). Neither microorganism shows evidence of a mutualistic relationship. Mutualistic relationships center around the two-way exchange of nutrients between the organisms (Harrison 1999). Most commonly, the nutrient exchange takes place through a specialized structure termed a haustorium (Hall and Williams 2000; Divon and Fluhr 2007). Although hyphal filaments are present within the embryo, no haustoria were discovered. Because of the presence of nuclei within the embryo and gametophyte, it was assumed that the preserved tissues were still metabolically active at the time of permineralization. It therefore seems unlikely that the microorganisms are saprotrophs. An oogonium of Combresomyces cornifer, a peronosporomycete, is present in megagametophyte tissue of the Telemachus plant (Schwendemann et al. 2010). The megagametophyte tissue directly surrounding the oogonium is highly degraded. Megagametophyte tissue elsewhere in the seed shows little sign of destruction. This suggests that C. cornifer was a necrotrophic parasite of the Telemachus plant. Immature sporocarps of Mycocarpon asterineum are found within the same seed (Schwendemann et al. 2010). The sporocarps are found in the area between the megagametophyte and megaspore membrane; the nearby plant tissue shows no sign of degradation (fig. 6D, $6 E$ ). It is possible for M. asterineum to be a parasitic microorganism without obvious signs of decay. Biotrophic parasites live within their hosts without actively destroying host tissues by using specialized haustoria (Divon and Fluhr 2007); no evidence of haustoria was found in the specimen, so it is still not known how M. asterineum interacted with the embryo.

Epiphyllous Fungi. Compressed Heidiphyllum leaves in particularly fine-grained sedimentary matrices at Allan Hills and Alfie's Elbow commonly show an exquisite preservation of epidermal and cuticular microrelief when viewed under oblique lighting. In some cases, the leaf surfaces are entirely covered with a dense network of fungal hyphae (fig. 6C). Finer details of these epiphyllous mycelia, however, are difficult to discern. 


\section{Evidence for the Affiliation of Taxa}

In the original descriptions, the various detached organs listed in the previous section have been interpreted as belonging to at least four different natural plant groups, including Voltziales (e.g., Telemachus, Heidiphyllum, and Leastrobus; Retallack 1981; Anderson and Anderson 1989; Hermsen et al. 2007), Podocarpaceae (Notophytum; Meyer-Berthaud and Taylor 1991; Axsmith et al. 1998), Taxodiaceae (Parasciadopitys; Yao et al. 1997), as well as an obscure group of seed ferns (Switzianthus; Anderson and Anderson 2003). These varying assignments result from a peculiar combination of features that are characteristic for very disparate groups of extant conifers; consider, for example, the Podocarpaceae-type pitting in Notophytum (Meyer-Berthaud and Taylor 1991) or the supposedly taxodiaceous characters of Parasciadopitys (Yao et al. 1997). We here present new data and synthesize information that has accumulated especially in recent years (Escapa et al. 2010; Bomfleur et al. 2011a; this study), which altogether provide compelling evidence that all these organs belong to a single natural genus complex of voltzialean conifers (fig. 7). The peculiar character combination among the different organs of these plants therefore likely reflects mosaic evolution in this conifer lineage.

The individual lines of evidence are listed in order of significance, beginning with organic connections as least controversial evidence and ending with association/disassociation data and ex situ palynology, which are less conclusive by themselves but provide important additional support. Altogether, two main subsets of affiliated organs can be recognized, one for compression taxa and one for permineralized taxa. Both subsets of organs are intricately linked via the structural correspondences between foliage and seed cone taxa, which merely represent the same organs in different preservational states (fig. 7).

Finally, given the overall scarcity of other conifer groups in the Triassic of Antarctica whose representatives could be potential alternative candidates for affiliation (see Escapa et al. 2011), the assignment of all the various different organs to a single group is also simply the most parsimonious hypothesis. We observed a total of probably more than 2000 Heidiphyllum leaves, 41 Telemachus seed cones, and 10 Switzianthus pollen cones in the University of Kansas paleobotanical collections. By comparison, the only other conifer taxa in the compression/impression collections are two isolated twigs of the podocarp Rissikia media; no other conifer pollen cones or seed cones occur, except perhaps for isolated scales of the alleged coniferophyte Dordrechtites (Escapa et al. 2011), which, however, has recently been reinterpreted as a probable seed fern reproductive structure (J. Bergene and E. L. Taylor, personal communication, 2012). In the silicified peat from Fremouw Peak, only Notophytum and Parasciadopitys are present; there is to date no evidence of any type of conifer stem, root, foliage, or cone different from the taxa reviewed in this article.

\section{Organic Connection}

The clearest evidence for the affiliation of some of the dispersed conifer taxa from the Triassic of Antarctica is the existence of organs in organic connection, which occurs in both permineralizations and compression/impression material.
Leaves, Stems, and Roots of Notophytum. Notophytum leaves occur in organic connection with young Notophytum stems (Meyer-Berthaud and Taylor 1991; fig. 4A, 4E). These authors also assigned co-occurring roots to Notophytum on the basis of similar anatomy. This assignment has been verified with the description of large roots with a Notophytum type of anatomy that produce young sucker shoots (fig. 4K) with leaves comparable to Notophytum (Decombeix et al. 2011).

Heidiphyllum Leaves and Telemachus Seed Cones (This Study). A compression specimen from Mount Falla shows Heidiphyllum leaves attached to a short shoot that terminally bears a small and compact, presumably immature Telemachus cone (fig. $2 H$ ).

\section{Structural Correspondence}

The remarkable structural correspondences between permineralizations and compression/impression material of both foliage and seed cones have led previous authors to suggest that the relevant taxa-that is, Notophytum and Heidiphyllum leaves and Telemachus and Parasciadopitys seed cones-may in fact represent different preservational states of parts of the same plants (Axsmith et al. 1998; Escapa et al. 2010). Additional evidence from newly collected material provides even further support for these interpretations.

Notophytum and Heidiphyllum Leaves. Anatomically preserved leaves attached to Notophytum krauselii stems (figs. $1 F, 1 I, 4 D, 4 E, 4 G, 4 I, 4 J)$ are indistinguishable from Heidiphyllum elongatum compression/impression foliage (figs. $1 A-1 E, 1 H$, $4 F, 4 H)$ in all observable morphological and anatomical characters (Axsmith et al. 1998). Similarities include the general shape and dimensions, the absence of a petiole, the parallel venation pattern and vein number between 8 and 12, and the interveinal "striae" (Axsmith et al. 1998); cuticle and epidermal similarities include the papillate lower epidermis as well as the size, shape, and arrangement of the adaxial epidermal cells. Moreover, both leaf types have been suggested to have been deciduous on the basis of independent lines of evidence (Retallack 1981; MeyerBerthaud and Taylor 1991; fig. $1 H, 1 J$ ). In addition, the new find of a short shoot with an attached Heidiphyllum leaf (fig. 1G) further confirms that both taxa had a tight, helical phyllotaxy.

Telemachus and Parasciadopitys Seed Cones. The recent description of Telemachus cones with preserved anatomical details (Escapa et al. 2010) has enabled a more detailed comparison to the permineralized cone Parasciadopitys. Escapa et al. (2010) demonstrated that the two taxa share even more structural features than previously recognized. Apart from overall morphological similarities (Yao et al. 1997), Telemachus (figs. 2A-2E, 5B, 5D, 5K) and Parasciadopitys (fig. 5A, 5C, $5 E-5 J)$ are now known to share the partial fusion of the bract and scale, the entire bract morphology, the number of five distal scale lobes, similar tissue type in bract and scale, the organization of the vascular system within the ovulate complex, the presence of thick-walled cells associated with the vascular strands, as well as the arrangement, orientation, shape, and general anatomy of the ovules. In the original description of Parasciadopitys, the major difference between this genus and Telemachus was suggested to be the different number of ovules per scale. While the number of ovules in Telemachus specimens 
is difficult to determine, all available evidence points to the presence of one ovule per scale lobe, that is, five ovules per scale, as is the case in Parasciadopitys. The length of the bract, which is one of the main differences between the two Antarctic species of Telemachus, is somewhat intermediary in Parasciadopitys. In overall dimensions, Parasciadopitys appears somewhat smaller than the Antarctic Telemachus species described so far, although it falls well within the size range of T. brachybractus described from South Africa (Anderson and Anderson 2003). By contrast, the ovules that we have been able to observe in Telemachus appear slightly smaller than those of Parasciadopitys. This could, however, be due to a different maturation stage of the ovules or simply to the fact that the available Telemachus sections are tangential and do not pass through the largest part of the ovules (for comparison, see the Parasciadopitys ovules sectioned at different levels in fig. 5G).

\section{Correspondence in Epidermal Anatomy and Cuticle Morphology}

Analysis of cuticle and epidermal features can be very useful for the affiliation of dispersed plant organs (Harris 1956; Kerp 1990). As has been outlined above, cuticles of Heidiphyllum and the associated cones in compression assemblages are very delicate and therefore difficult to obtain and to successfully prepare. As a result, cuticle and epidermal features of compression material of the Gondwanan voltzialean conifers continue to remain poorly known. The few data available, however, provide further support for an affiliation (Bomfleur et al. 2011a).

The cuticles of Heidiphyllum leaves (Anderson 1978; Anderson and Anderson 1989), of Telemachus cone scale bases (Yao et al. 1993), and of the distal microsporophyll laminae of Switzianthus (Anderson and Anderson 2003) all bear sunken stoma surrounded by a complete ring of five to six prominently thickened subsidiary cells. Laminate organs-that is, Heidiphyllum leaves and the microsporophyll laminae of Switzianthus-have furthermore been shown to be predominantly hypostomatic or weakly amphistomatic. Cuticles of the lower epiderme are papillate.

\section{Association/Disassociation Data}

Data on mutual occurrences of fossil plant organs can provide important evidence for affiliation (Kvaček 2008; Bateman and Hilton 2009), given that potential bias sources (Gastaldo 1992; Behrensmeyer et al. 2000) are critically evaluated.

Telemachus, Heidiphyllum, and Switzianthus. Mutual occurrence data for the abundant voltzialean leaves (Heidiphyllum) and seed cones (Telemachus) in Triassic deposits across Gondwana (Frenguelli 1942; Anderson 1978; Retallack 1981; Yao et al. 1993) are so comprehensive and significant that an affiliation of these two genera based on mutual occurrence alone can be considered unequivocal (see Anderson and Anderson 2003). For the rare reports of Switzianthus, cooccurrence data are obviously less comprehensive; Switzianthus was initially interpreted to be affiliated to the pteridosperm foliage Dejerseya on the basis of association at some South African localities (Anderson and Anderson 2003). With additional finds from Antarctica, however, Bomfleur et al. (2011a) pointed out that Switzianthus is known from extensively sampled localities in which Dejerseya is absent and that it is, by contrast, invariably associated with Heidiphyllum foliage at all known localities. Co-occurrence of Switzianthus with Telemachus seed cones is less conclusive in South Africa (see Anderson and Anderson 2003, table. 28) but evident in the Antarctic assemblages, where Switzianthus is associated with Telemachus at both sites in the Allan Hills and Mount Falla. Of particular significance in this context is the Mount Falla plant-fossil assemblage, whose relatively large sample size and low diversity made it possible to reassemble the different organs of the three constituting gymnosperm plants, including one conifer comprising Heidiphyllum leaves, Telemachus seed cones, and Switzianthus pollen cones (Bomfleur et al. 2011b).

Notophytum (Stems, Leaves, and Roots) and Parasciadopitys Seed Cones (This Study). The type material of Parasciadopitys (Yao et al. 1997) occurs in peat blocks that almost exclusively contain various organs of Notophytum, including leaves, roots, and, in one case, a young stem. Thus, it appears that, in addition to their structural similarities, the seed cones Parasciadopitys and Telemachus each co-occur with leaves that themselves show structural similarities: Parasciadopitys with Notophytum, and Telemachus with Heidiphyllum.

\section{Ex Situ Palynology}

Telemachus, Parasciadopitys, Switzianthus, and Alisporites Pollen. The reproductive organs of the Triassic Voltziales from Gondwana are all associated with bisaccate pollen that conforms most favorably to the dispersed-pollen genus Alisporites sensu lato (Yao et al. 1993; Anderson and Anderson 2003; Bomfleur et al. 2011a; this study; see also Hermsen et al. 2007). This evidence, however, requires a critical evaluation.

Ideally, palynological evidence can provide substantial proof for affiliating dispersed reproductive organs. This is the case when distinctive pollen can be demonstrated to occur in situ both in microsporangia (in situ meaning, e.g., enclosed in pollen sacs) as well as in ovulate organs (in situ meaning, e.g., occurring in the pollen chambers of developing seeds). In the case of the present material, however, palynological evidence is less conclusive. First, the pollen grains reported for Switzianthus (Anderson and Anderson 2003; Bomfleur et al. 2011a), for Telemachus (Yao et al. 1993), and for Parasciadopitys (this study; fig. 5I) occur ex situ in all instances. Pollen extracted from Switzianthus cones has not been found enclosed inside pollen sacs, even though the high abundance and occurrence in distinctly large pollen grain clusters make an affiliation highly likely (Anderson and Anderson 2003; Bomfleur et al. 2011a). Alisporites pollen grains occur also in large numbers attached to the cone scale cuticles of Telemachus (Yao et al. 1993), but cuticles of actual seeds, which might contain these affiliated pollen grains in situ, could not be recovered. Similarly, in the permineralized Parasciadopitys, abundant bisaccate, sulcate grains have as yet only been found dispersed in the matrix around the cone scales (this study; fig. $5 H$ ). In addition, the dispersed-pollen genus Alisporites sensu lato is known to have been produced by at least three different groups of gymnosperms during the Triassic, including voltzialean conifers as well as corystospermalean and peltaspermalean seed ferns (see Balme 1995).

Therefore, the so far available ex situ palynological evidence should be considered rather as co-occurrence data that 
provide further support mainly in as much as they are compatible with interpretations based on other lines of evidence.

\section{Nomenclatural Issues}

Whole-plant reconstructions in general include several individual organs that, in most cases, have been previously described and named as individual species. This makes naming a whole-plant reconstruction often a challenging task (Chaloner 1986; Bateman and Hilton 2009). A list of the binomials of all included organ species in the new plant concept has recently been suggested as the only effective way to accurately name the reconstructed fossil plant (see Bateman and Hilton 2009). However, if only for practical purposes, a single name for the reconstructed plant is desirable. Following the simple principle of priority, the earliest name among the included organ taxa might be used. However, the strict use of the principle of priority in naming reconstructed plants can easily lead to taxonomic problems. For instance, the oldest name among the included organ species may happen to refer to a highly homoplastic organ. In such case, the same name might eventually be applied to an entirely different whole-plant taxon, in case it possesses that same name-bringing organ species among its parts; as an example, consider the foliage morphogenus Taeniopteris, which is known to occur in representatives of not less than four different plant orders, including various gymnosperms (Cycadales, Bennettitales, Pentoxylales) as well as marattialean ferns. Hence, if only one name is to be applied to the whole-plant taxon, it should be based on that organ that is interpreted to contain the most (or the most significant) autapomorphic characters (autapo-taxon of Bateman and Hilton 2009). In this case, the organ with the most significant set of diagnostic autapomorphic character states is the included seed cone Telemachus, which, by fortunate coincidence, is also the oldest valid name among the various taxa considered.

Our whole-plant concept is established mainly on the basis of generic characters. As can easily be inferred from the number of Telemachus species described to date (see Escapa et al. 2010), possibly more than nine natural species may fall within our conceptual whole-plant reconstruction; the overall vegetative characters (including, e.g., foliage morphology, wood anatomy, growth habit) and ecological characteristics of the individual species, however, appear to be rather uniform. As a result, we propose a whole-plant reconstruction at the genus level and opt to refer to the plants in open nomenclature as Telemachus conifers/ Telemachus trees, following the suggestions recently advanced by Bateman and Hilton (2010) and Cleal and Thomas (2010).

\section{Taxonomic Implications}

The detailed comparisons based on newly available material described above confirm the assumptions of previous authors that the relevant foliage taxa (Heidiphyllum and Notophytum leaves) and seed cone taxa (Telemachus and Parasciadopitys seed cones) represent the same genera in different states of preservation (see Axsmith et al. 1998; Escapa et al. 2010). As a consequence, we suggest that (1) isolated leaves of Notophytum krauselii may be equally identified as permineralized $\mathrm{Hei}$ - diphyllum elongatum and that (2) the genus Parasciadopitys should be considered as a junior synonym of Telemachus, and the use of the name abandoned.

With its comparatively short bracts, the type and so far only species of the genus Parasciadopitys-that is, Parasciadopitys aequata-appears superficially similar to the species Telemachus antarcticus. Because the diagnostically significant characters used for species delimitation in Telemachus are, however, difficult to observe in the permineralized state, we suggest retaining a separate species, Telemachus aequatus (Yao, Taylor et Taylor) nov. comb. (see appendix), at least until more completely preserved material enables a more detailed evaluation.

\section{Paleobiological and Paleoecological Aspects}

\section{Habit Reconstruction}

The wealth of morphological and anatomical information on the individual organs allows us to propose a detailed habit reconstruction of Telemachus conifers (fig. 8). For the stems and branches (Notophytum krauselii), profuse, orthotropic branching in up to at least four orders has been described (Meyer-Berthaud and Taylor 1991). The branching pattern is helical throughout and is characterized by an alternation of widely spaced branches and contracted branch groups that form pseudowhorls (Meyer-Berthaud and Taylor 1991), indicating rhythmic growth. The architecture of Notophytum therefore most likely follows Rauh's tree architectural model, which is characterized by essentially orthotropic branching and rhythmic growth (Halle and Oldeman 1970; Robinson 2000). A slight modification occurs in the form of the production of short and long shoots (brachy- and macroblasts), as evidenced by the rare finds of Heidiphyllum leaves that are attached to short shoots (Anderson and Anderson 2003; this study; fig. $1 G)$. Furthermore, it has been shown that these conifers were seasonally deciduous (see "Foliage (Figs. 1, 4D-4J)"). When compared with extant conifers, the architecture and growth habit of the Telemachus conifers therefore appear surprisingly similar to those of extant larch (Larix L.; Caccianiga and Compostella 2011). On the basis of the occurrence at very high latitudes well within the polar circle (see "Paleoecology and Paleoenvironment"), it is reasonable to assume that the Telemachus trees produced a tall, conical crown structure; this growth form is predominant among extant high-latitude trees because of its much more efficient interception of the low-angle irradiation prevailing in high-latitude regions (Jahnke and Lawrence 1965; Oker-Blom and Kelomaki 1982; Creber and Chaloner 1984; Kuuluvainen 1992). The largest Notophytum stems recorded so far exceed $20 \mathrm{~cm}$ in diameter (Meyer-Berthaud and Taylor 1991, 1992; fig. 3A-3C). On the basis of observed stem diameter/height relationships of extant trees (Niklas 1994) and of the overall comparable genus Larix in particular (see Huang et al. 1992), we estimate that the Telemachus plants were medium-sized forest trees reaching $\sim 15-20 \mathrm{~m}$ in height.

There is even some evidence of reiteration in the architecture of the Telemachus trees in the form of the common development of dense groups of offshoots that arise from large roots and trunk bases (Notophytum; Decombeix et al. 2011; figs. $3 B, 3 C, 4 K)$. By analogy with extant trees, however, we 

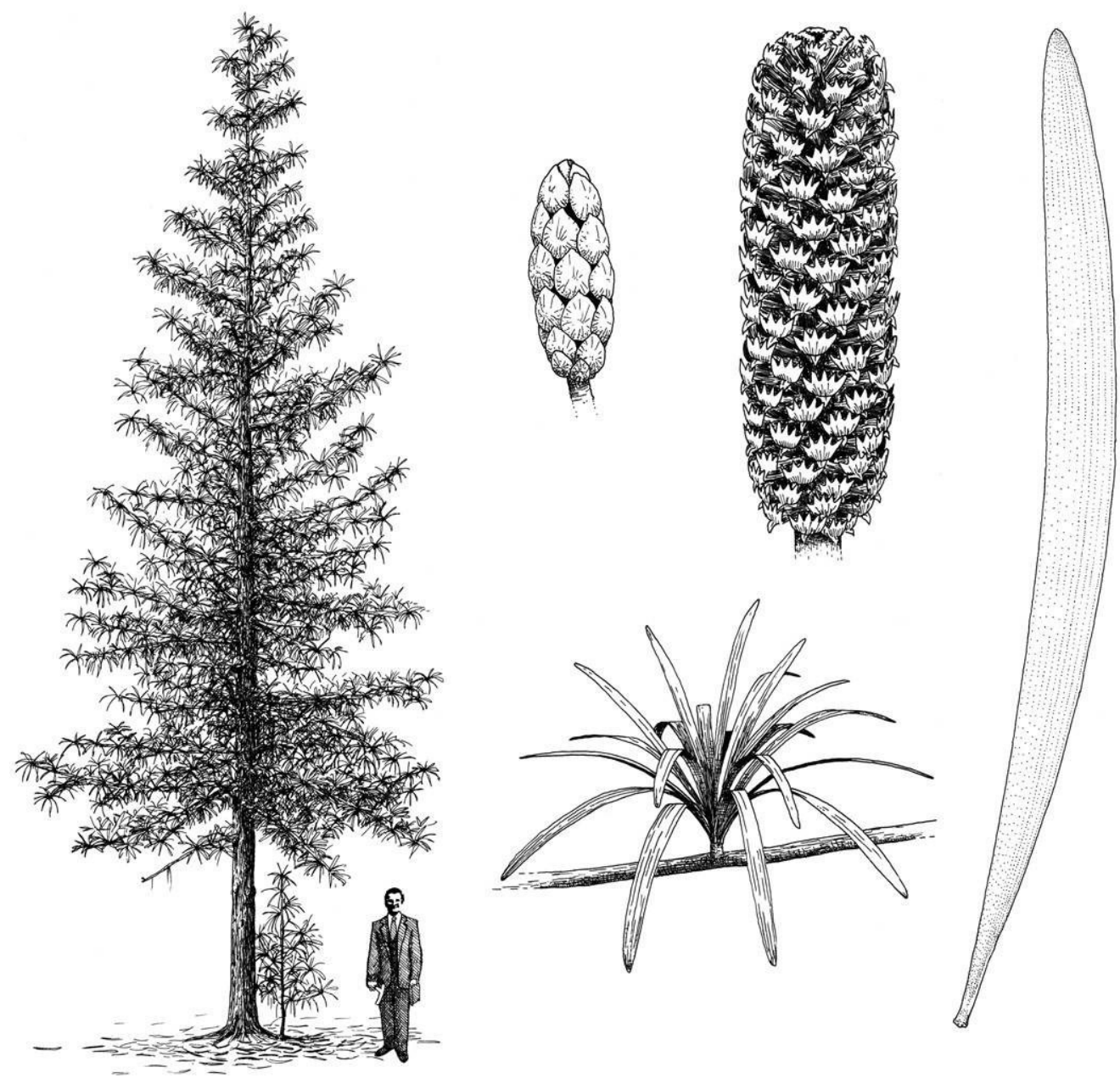

Fig. 8 Suggested reconstruction of the various organs of a Triassic Telemachus conifer from present-day Antarctica. For a detailed explanation, see "Habit Reconstruction." The figure of Thomas N. Taylor $(\sim 180 \mathrm{~cm})$ is provided for scale.

assume that only few of the abundant root suckers actually continued developing into young new trees.

An exceptional find of attached leaves from the Molteno Formation of South Africa demonstrates that the foliage was borne in dense clusters on short shoots (see Anderson and Anderson 1989). In addition, a relatively thick short shoot with an attached basal leaf portion and with densely disposed, characteristically crescent-shaped leaf scars occurs in the collection from Mount Falla, Central Transantarctic Mountains (fig. 1G). Anatomically preserved material from Fremouw Peak indicates that the leaf phyllotaxy was either in a single helix or in two opposite helices, that is, bijugate (Meyer-Berthaud and Taylor 1992). On the basis of the extensive and lavishly illustrated collection of Heidiphyllum leaves from South Africa, Anderson and Anderson (1989) have shown that the shape and dimensions of the foliage are variable; the most common type in Antarctic deposits, however, comprises straight or slightly curving, strap-shaped or narrow-elliptic leaves with a width of $1-2 \mathrm{~cm}$ and a length of $\sim 20-25 \mathrm{~cm}$. Hence, it can be assumed that the foliage of the Telemachus conifers formed dense, more or less hemispherical clusters with diameters of $\sim 30-40 \mathrm{~cm}$. Taphonomic data and anatomical details (see "Foliage (Figs. 1,
$4 D-4 J)$ "; fig. $1 H, 1 I)$ indicate that the deciduous leaves were most likely shed on a seasonal basis (Meyer-Berthaud and Taylor 1991; Axsmith et al. 1998).

The exact position of the cones in the tree remains unclear. Telemachus seed cones have been found terminally attached to shoot systems. More commonly, these are long shoots bearing remains of triangular, closely adpressed, scale-like modified leaves (fig. 2A; see also Anderson and Anderson 2003, plates 11, 12). A single specimen from the Falla Formation in the Central Transantarctic Mountains, however, consists of a small, compact, presumably immature cone that appears to be borne on a short shoot with attached remains of densely disposed, regular Heidiphyllum leaves (fig. $2 H$ ).

Altogether, the Telemachus plants are reconstructed as medium-sized forest trees with a vertical, narrow-conical crown shape, profuse branching, and dense foliation composed of clusters of long, multiveined leaves (fig. 8).

\section{Paleoecology and Paleoenvironment}

Voltzialean foliage is among the most common and typical plant fossils in the Triassic of the Southern Hemisphere, being 
represented in most Triassic plant-fossil assemblages from Antarctica, Australia, New Zealand, South Africa, and South America (Anderson and Anderson 1989, 2003; Artabe et al. 2001; Escapa et al. 2011). During the Middle and Late Triassic, these areas lay in the southern realm of Gondwana in mid- to high latitudes between $\sim 55^{\circ} \mathrm{S}$ and $85^{\circ} \mathrm{S}$ (Lawver and Scotese 1987; Lawver et al. 1998; Scotese 2004; Veevers 2004; Golonka 2007). Earth during that time was a greenhouse world; independent lines of evidence indicate that the climatic conditions in South Polar latitudes were mesothermal and humid, with high rainfall throughout the year and no notable periods of subzero temperatures (Hammer et al. 1990; Parrish 1990; Collinson 1997; Retallack and Alonzo-Zarza 1998; Taylor et al. 2000; Taylor and Ryberg 2007; Hermsen et al. 2009). These favorable conditions sustained lush and very diverse vegetation across the mid- and high-latitude regions of Gondwana (Taylor et al. 2000; Anderson and Anderson 2003; Escapa et al. 2011). The Telemachus conifers were particularly abundant and, in many cases, dominant in distinct plant-fossil associations with characteristic paleoenvironmental settings.

Low-diversity, in some cases almost monospecific Heidiphyllum assemblages with associated Telemachus cones occur commonly in fine-grained overbank deposits that accumulated in floodbasin environments with high water tables (Cairncross et al. 1995; Anderson et al. 1998), often associated with the formation of hygromorphic soils (Bomfleur and Kerp 2010) and peat (Axsmith et al. 1998). Typically associated understory plants in these low-diverse vegetation types include either osmundaceous ferns or sphenophytes (Gabites 1985; MeyerBerthaud and Taylor 1991; Boucher et al. 1995; Anderson et al. 1998; Phipps et al. 1998; Bomfleur and Kerp 2010). Differences in the preservation mode and in the composition of herbaceous understory may reflect different degrees of waterlogging. The particular permineralized peat facies yielding voltzialean remains contains almost exclusively Notophytum stems, roots, and leaves; Parasciadopitys cones; and the anatomically preserved, Equisetum-like sphenophyte Spaciinodum collinsonii (Meyer-Berthaud and Taylor 1991; Schwendemann et al. 2011; this study). The peat formation indicates that this deposit formed under at least periodically waterlogged conditions that prevented further decomposition of the plant debris. The astonishing conservation of subcellular detail in a voltzialean embryo (Schwendemann et al. 2010; see fig. 6D) provides an impressive example for this exquisite preservation potential. The records of very short-lived physiological exchange structures of mycorrhizal fungi in Notophytum roots (Schwendemann et al. 2010; C. J. Harper, personal communication, 2012) prove that these conifers must have grown in situ in the peat substrate and that this peat likely formed through autochthonous accumulation of leaf litter and woody debris of the voltzialean conifers themselves (see also Axsmith et al. 1998).

In this context, the here described evidence for odonatan oviposition on Heidiphyllum leaves is of particular significance for paleoenvironmental interpretations. Among living members of Odonata, endophytic oviposition is restricted to plant parts that are in the immediate vicinity of freshwater, so that the (pro)nymphs can simply drop into their aquatic larval stage environment directly after hatching (see Van Konijnenburg-van Cittert and Schmeißner 1999). By analogy, the odonatan oviposition on a Heidiphyllum leaf provides further support to suggest that the Telemachus trees were tolerant of growing very close to or even within freshwater bodies, with parts of the leafy twigs overhanging an open water surface.

In addition, the Gondwanan Telemachus conifers were conspicuously abundant in plant-fossil assemblages that have been interpreted to represent immature woodland communities colonizing silty floodplain areas (Retallack 1977; Retallack and Alonso-Zarza 1998; see also Bomfleur et al. 2011b) and larger channel sandbars (Cairncross et al. 1995; Anderson et al. 1998), where they were commonly associated with peltaspermalean and petriellalean seed ferns (Anderson and Anderson 2003; Bomfleur et al. 2011b, and references therein). Further support for interpreting the Telemachus plants as potentially early successional trees in immature bottomland forests is the presence of at least two types of elaborate associations with vesicular-arbuscular mycorrhizae in Notophytum roots. In temperate and boreal forest communities today, the mycorrhizal status shows distinct changes in the course of succession: (facultative) vesiculararbuscular mycorrhizae associations are dominant in early successional tree species in immature forests, whereas, by contrast, ectomycorrhizal association is required to sustain tree growth in more diversified climax communities on mineralimpoverished substrates (Francis and Read 1994).

In conclusion, we interpret the Telemachus trees as the dominant components of peat-forming conifer swamps, forest bogs, and immature bottomland forests in the Triassic high-latitude flood basins of southern Gondwana. We suggest that analogous extant environments may to some degree be found in the peat-forming forested wetlands in temperate zones of the Northern Hemisphere today, in which deciduous tamarack (Larix laricina), osmundaceous ferns, and horsetails form dominant floral components.

\section{Acknowledgments}

This contribution is dedicated to Thomas N. Taylor on the occasion of his seventy-fifth birthday. We wish to thank Tom for the invaluable encouragement and advice that he gave each of us during various times in our careers. We thank Gar Rothwell and Ruth Stockey for the kind invitation to participate in this special volume. We gratefully acknowledge valuable discussion with Carla J. Harper (Lawrence, KS) about her current work in progress on mycorrhizae in Notophytum roots. This work was funded in part by the National Science Foundation (OPP-0943934 to E. L. Taylor and T. N. Taylor; 2010-2011 field work), the Alexander von Humboldt Foundation (Feodor Lynen fellowship to B. Bomfleur), and the Centre National de la Recherche Scientifique (CNRS; Unité Mixte de Recherche [UMR] 5120; travel funds to A.-L. Decombeix). Botanique et Bioinformatique de l'Architecture des Plantes (Botany and Computational Plant Architecture) is a joint research unit that associates the Centre de Coopération Internationale en Recherche Agronomique pour le Développement (UMR51), CNRS (UMR5120), Institut National de la Recherche Agronomique (UMR931), Institut de Recherche pour le Développement (R123), and Montpellier 2 University (UM27; http://amap.cirad.fr/). 


\section{Appendix}

\section{Taxonomic Revision}

\section{Order-Voltziales Anderson et Anderson}

Family-Voltziaceae Florin

Genus-Telemachus Anderson Emend. Escapa,
Decombeix, Taylor et Taylor

Type. Telemachus elongatus Anderson 1978 emend. Escapa, Decombeix, Taylor et Taylor 2011.
Synonym. Parasciadopitys Yao, Taylor et Taylor 1997, p. 343.

Remarks. For reasons outlined in the discussion, we suggest that the genus Parasciadopitys be considered a junior synonym of Telemachus and that the type and only species Parasciadopitys aequata be transferred into a new combination Telemachus aequatus.

Species. Telemachus aequatus (Yao, Taylor et Taylor) comb. nov. Bomfleur et al.

Basionym. Parasciadopitys aequata Yao, Taylor et Taylor 1997, p. 343f.

\section{Literature Cited}

Anderson HM 1978 Podozamites and associated cones and scales from the Upper Triassic Molteno Formation, Karoo Basin, South Africa. Palaeontol Afr 21:57-77.

Anderson JM, HM Anderson 1989 Palaeoflora of Southern Africa: Molteno Formation (Triassic). Vol 2. Gymnosperms (excluding Dicroidium). Balkema, Rotterdam.

- 2003 Heyday of the gymnosperms: systematics and biodiversity of the Late Triassic Molteno fructifications. National Botanical Institute, Pretoria.

Anderson JM, HM Anderson, ARI Cruickshank 1998 Late Triassic ecosystems of the Molteno/lower Elliot biome of southern Africa. Palaeontology 41:387-421.

Artabe AE, EM Morel, LA Spalletti 2001 Paleoecología de las floras Triásicas Argentinas. Pages 199-225 in AE Artabe, EM Morel, AB Zamuner, eds. El Sistema Triásico en la Argentina. Fundación Museo de La Plata "Francisco Pascasio Moreno," La Plata.

Axsmith BJ, TN Taylor, EL Taylor 1998 Anatomically preserved leaves of the conifer Notophytum krauselii (Podocarpaceae) from the Triassic of Antarctica. Am J Bot 85:704-713.

Balme BE 1995 Fossil in situ spores and pollen grains: annotated catalogue. Rev Palaeobot Palynol 87:81-323.

Bateman RM, J Hilton 2009 Palaeobotanical systematics for the phylogenetic age: applying organ-species, form-species and phylogenetic species concepts in a framework of reconstructed fossil and extant whole-plants. Taxon 58:1254-1280.

2010 Proposals to modify the provisions in the Code for naming fossil plants. Taxon 59:1623-1625.

Bateman RM, GW Rothwell 1990 A reappraisal of the Dinantian floras at Oxroad Bay, East Lothian, Scotland. 1. Floristics and the development of whole-plant concepts. Trans R Soc Edinb 81:127159.

Behrensmeyer AK, SM Kidwell, RA Gastaldo 2000 Taphonomy and paleobiology. Paleobiology 26(suppl):103-147.

Bomfleur B, H Kerp 2010 Dicroidium diversity in the Upper Triassic of North Victoria Land, East Antarctica. Rev Palaeobot Palynol 160:67-101.

Bomfleur B, R Serbet, EL Taylor, TN Taylor 2011a The possible pollen cone of the Late Triassic conifer Heidiphyllum/Telemachus (Voltziales) from Antarctica. Antarct Sci 23:379-385.

Bomfleur B, EL Taylor, TN Taylor, R Serbet, M Krings, H Kerp $2011 b$ Systematics and paleoecology of a new peltaspermalean seed fern from the Triassic polar vegetation of Gondwana. Int J Plant Sci 172:807-835.

Boucher LD, EL Taylor, TN Taylor, NR Cúneo, JM Osborn 1995 Dicroidium compression floras from southern Victoria Land. Antarct J U S 30:40-41.

Caccianiga M, C Compostella 2011 Growth forms and age estimation of treeline species. Trees 26:331-342.

Cairncross B 1995 Palaeoecology of the Triassic Molteno Formation,
Karoo Basin, South Africa: sedimentological and palaeontological evidence. S Afr J Geol 98:452-478.

Chaloner WG 1986 Reassembling the whole fossil plant, and naming it. Pages 67-78 in RA Spicer, BA Thomas, eds. Systematic and taxonomic approaches in palaeobotany. Clarendon, Oxford.

Cleal CJ, BA Thomas 2010 Botanical nomenclature and plant fossils. Taxon 59:261-268.

Collinson JW 1997 Paleoclimate of Permo-Triassic Antarctica. Pages 1029-1034 in CA Ricci, ed. The Antarctic region: geological evolution and processes. Terra Antarctica, Siena.

Crane PR 1984 A re-evaluation of Cercidiphyllum-like plant fossils from the British early Tertiary. Bot J Linn Soc 89:199-230.

Creber GT, WG Chaloner 1984 Influence of environmental factors on the wood structure of living and fossil trees. Bot Rev 50:357-448.

Cúneo NR, EL Taylor, TN Taylor, M Krings 2003 In situ fossil forest from the upper Fremouw Formation (Triassic) of Antarctica: paleoenvironmental setting and paleoclimate analysis. Palaeogeogr Palaeoclimatol Palaeoecol 197:239-261.

Decombeix A-L, EL Taylor, TN Taylor 2011 Root suckering in a Triassic conifer from Antarctica paleoecological and evolutionary implications. Am J Bot 98:1222-1225.

Dilcher DL 1991 The importance of anatomy and whole plant reconstructions in palaeobotany. Curr Sci 61:627-629.

DiMichele WA, RA Gastaldo 2008 Plant paleoecology in deep time. Ann Mo Bot Gard 95:144-198.

Divon HH, R Fluhr 2007 Nutrition acquisition strategies during fungal infection of plants. FEMS Microbiol Lett 266:65-74.

Dunn MT, P Atkinson, J Lacefield, M Rischbieter 2012 Winslowia tuscumbiana gen. et sp. nov. (Chaloneriaceae): a cormose, heterosporous, ligulate lycopsid reconstructed from the inside out from the Pride Mountain Formation (Late Mississippian/Serpukhovian) of Northern Alabama. Int J Plant Sci 173:96-111.

Esau K 1965 Plant anatomy. 2nd ed. Wiley, New York.

Escapa IH, A-L Decombeix, TN Taylor, EL Taylor 2010 Evolution and relationships of the conifer Telemachus: evidence from the Triassic of Antarctica. Int J Plant Sci 171:560-573.

Escapa IH, EL Taylor, R Cuneo, B Bomfleur, J Bergene, R Serbet, TN Taylor 2011 Triassic floras of Antarctica: plant diversity and distribution in high paleolatitude communities. PALAIOS 26:522-544.

Francis R, DJ Read 1994 The contributions of mycorrhizal fungi to the determination of plant community structure. Plant Soil 159:11-25.

Frenguelli J 1942 Contribuciones al conocimiento de la flora del Gondwana Superior en la Argentina. II. Notas Mus Univ Nac Plata VII Paleontol 43:275-286.

Gabites HI 1985 Triassic Paleoecology of the Lashly Formation, Transantarctic Mountains, Antarctica. MS thesis. Victoria University of Wellington.

Galtier J 1986 Taxonomic problems due to preservation: comparing compression and permineralized taxa. Pages 1-16 in RA Spicer, BA 
Thomas, eds. Systematic and taxonomic approaches in palaeobotany. Clarendon, Oxford.

Galtier J, TL Phillips 1999 The acetate peel technique. Pages 67-70 in TP Jones, NP Rowe, eds. Fossil plants and spores: modern techniques. Geological Society, London.

Gastaldo RA 1992 Taphonomic considerations for plant evolutionary investigations. Palaeobotanist 41:211-223.

Golonka J 2007 Late Triassic and Early Jurassic palaeogeography of the world. Palaeogeogr Palaeoclimatol Palaeoecol 244:297-307.

Grand'Eury FC 1877 Flore Carbonifère du Département de la Loire et du centre de la France. Mémoires Présentés par Divers Savants à l'Académie des Sciences de l'Institut de France 24(1):1-348.

Grauvogel-Stamm L, K-P Kelber 1996 Plant-insect interactions and coevolution during the Triassic in western Europe. Paleontol Lombardia 5:5-23.

Hall JL, LE Williams 2000 Assimilate transport and partitioning in fungal biotrophic interactions. Aust J Plant Physiol 27:549-560.

Hallé F, Oldeman RA 1970 Essai sur l'architecture et la dynamique de croissance des arbres tropicaux. Masson et Cie, Paris.

Hammer WR 1990 Triassic terrestrial vertebrate faunas of Antarctica. Pages 42-50 in TN Taylor, EL Taylor, eds. Antarctic paleobiology: its role in the reconstruction of Gondwana. Springer, New York.

Harris TM 1956 The fossil plant cuticle. Endeavour 15:210-214.

1976 Two neglected aspects of fossil conifers. Am J Bot 63: 902-910.

Harrison MJ 1999 Biotrophic interfaces and nutrient transport in plant/fungal symbioses. J Exp Bot 50:1013-1022.

Hermsen EJ, TN Taylor, EL Taylor 2007 A voltzialean pollen cone from the Triassic of Antarctica. Rev Palaeobot Palynol 144:113-122.

Hermsen EJ, EL Taylor, TN Taylor 2009 Morphology and ecology of the Antarcticycas plant. Rev Palaeobot Palynol 153:108-123.

Huang S, SJ Titus, DP Wiens 1992 Comparison of nonlinear heightdiameter function for major Alberta tree species. Can J For Res 22: 1297-1304.

Jahnke LS, DB Lawrence 1965 Influence of photosynthetic crown structure on potential productivity of vegetation, based primarily on mathematical models. Ecology 46:319-326.

Kerp H 1990 The study of fossil gymnosperms by means of cuticular analysis. PALAIOS 5:548-569.

Khan AG, PG Valder 1972 The occurrence of root nodules in the Ginkgoales, Taxales, and Coniferales. Proc Linn Soc N S W 97:35-43.

Krassilov V, A Rasnitsyn 2008 Plant-arthropod interactions in the early angiosperm history: evidence from the Cretaceous of Israel. Pensoft, Sofia.

Kuuluvainen T 1992 Tree architectures adapted to efficient light utilization: is there a basis for latitudinal gradients? Oikos 65:275-284.

Kvaček Z 2008 Whole-plant reconstructions in fossil angiosperm research. Int J Plant Sci 169:918-927.

Labandeira CC, P Wilf, KR Johnson, F Marsh 2007 Guide to insect (and other) damage types on compressed plant fossils. Version 3.0. Smithsonian Institution, Washington, DC.

Lawver LA, LM Gahagan, IWD Dalziel 1998 A tight fit: Early Mesozoic Gondwana, a plate reconstruction perspective. Mem Natl Inst Polar Res Spec Issue 53:214-229.

Lawver LA, CR Scotese 1987 A revised reconstruction of Gondwanaland. Pages 17-23 in GD McKenzie, ed. Gondwana Six: structure, tectonics, and geophysics. American Geophysical Union, Washington, DC.

Lutz AI 2006 Estudio de la paleoflora de la Formación Carrizal (Triásico Superior), Cuenca de Marayes-El Carrizal, San Juan, Argentina. PhD thesis. Universidad Nacional del Nordeste, Corrientes.

Maheshwari HK 1972 Permian wood from Antarctica and revision of some lower Gondwana wood taxa. Palaeontogr Abt 138B:1-43. Meyer-Berthaud B, TN Taylor 1991 A probable conifer with podocarpacean affinities from the Triassic of Antarctica. Rev Palaeobot Palynol 67:179-198.

1992 Permineralized conifer axes from the Triassic of Antarctica. Cour Forschunginst Senckenb 147:191-197.

Millay MA, TN Taylor, EL Taylor 1987 Phi thickenings in fossil seed plants from Antarctica. IAWA Bull 8:191-201.

Morel EM 1994 El Triásico del Cerro Cacheuta, Mendoza (Argentina). I. Geología, contenido paleoflorístico y cronoestratigrafía. Ameghiniana 31:161-176.

Morel EM, AE Artabe, DG Ganuza, A Zúñiga 2011 La paleoflora TriAsica del Cerro Cacheuta, Provincia de Mandoza, Argentina: Petriellales, Cycadales, Ginkgoales, Voltziales, Coniferales, Gnetales y gimnospermas incertae sedis. Ameghiniana 48:520-540.

Morrison TM, DA English 1967 The significance of mycorrhizal nodules of Agathis australis. New Phytol 66:245-250.

Nielsen SN 2005 The Triassic Santa Juana Formation at the lower Biobío River, south central Chile. J S Am Earth Sci 19:547-562.

Niklas KJ 1994 Predicting the height of fossil plant remains: an allometric approach to an old problem. Am J Bot 81:1235-1242.

Oker-Blom P, S Kelomaki 1982 Theoretical computations on the role of crown shape in the absorption of light by forest trees. Math Biosci 59:291-312.

Oliver FW, DH Scott 1904 On the structure of the Palaeozoic seed Lagenostomalomaxi, with a statement of the evidence upon which it is referred to Lyginodendron. Philos Trans R Soc B 197:193-247.

Parrish JT 1990 Gondwanan paleogeography and paleoclimatology. Pages 15-26 in TN Taylor, EL Taylor, eds. Antarctic paleobiology: its role in the reconstruction of Gondwana. Springer, New York.

Phipps CJ, TN Taylor, EL Taylor, NR Cúneo, LD Boucher, X Yao 1998 Osmunda (Osmundaceae) from the Triassic of Antarctica: an example of evolutionary stasis. Am J Bot 85:888-895.

Prasad MNV 1982 An annotated synopsis of Indian Palaeozoic gymnospermous woods. Rev Palaeobot Palynol 38:119-156.

Retallack GJ 1977 Reconstructing Triassic vegetation of eastern Australasia: a new approach for the biostratigraphy of Gondwanaland. Alcheringa 1:247-277.

1981 Middle Triassic megafossil plants from Long Gully, near Otematata, north Otago, New Zealand. J R Soc N Z 11:167-200.

Retallack GJ, AM Alonso-Zarza 1998 Middle Triassic paleosols and paleoclimate of Antarctica. J Sediment Res 68:169-184.

Robinson DF 2000 Three gradients in the architecture of trees. Ann For Sci 57:439-444.

Russell AJ, MI Bidartondo, BG Butterfield 2002 The root nodules of the Podocarpaceae harbour arbuscular mycorrhizal fungi. New Phytol 156:283-295.

Sarzetti LC, CC Labandeira, J Javier Muzón, P Wilf, NR Cúneo, KR Johnson, JF Genise 2009 Odonatan endophytic pviposition from the Eocene of Patagonia: the ichnogenus Paleoovoidus and implications for behavioral stasis. J Paleontol 83:431-447.

Scheublin TR, KP Ridgway, JPW Young, MGA van der Heijden 2004 Nonlegumes, legumes, and root nodules harbor different arbuscular mycorrhizal fungal communities. Appl Environ Microbiol 70:6240-6246.

Schwendemann AB, A-L Decombeix, TN Taylor, EL Taylor, M Krings 2011 Morphological and functional stasis in mycorrhizal root nodules as exhibited by a Triassic conifer. Proc Natl Acad Sci USA 108:13630-13634.

Schwendemann AB, TN Taylor, EL Taylor, M Krings 2010 Organization, anatomy, and fungal endophytes of a Triassic conifer embryo. Am J Bot 97:1873-1883.

Scotese CR 2004 A continental drift flipbook. J Geology 112:729-741.

Stewart WN, GW Rothwell 1993 Paleobotany and the evolution of plants. Cambridge University Press, Cambridge.

Taylor EL, PE Ryberg 2007 Tree growth at polar latitudes based on fossil tree ring analysis. Palaeogeogr Palaeoclimatol Palaeoecol 255:246-264. 
Taylor EL, TN Taylor, NR Cúneo 2000 Permian and Triassic high latitude paleoclimates: evidence from fossil biotas. Pages 321-350 in BT Huber, KG MacLeod, SL Wing, eds. Warm climates in earth history. Cambridge University Press, Cambridge.

Taylor TN, EL Taylor, M Krings 2009 Paleobotany: the biology and evolution of fossil plants. 2nd ed. Academic Press, Burlington, MA.

Unger F 1847 Chloris protogaea. Engelmann, Leipzig.

van Konijnenburg-van Cittert JHA, S Schmeißner 1999 Fossil insect eggs on Lower Jurassic plant remains from Bavaria (Germany). Palaeogeogr Palaeoclimatol Palaeoecol 152:215-223.

Vasilenko DV 2005 Damages on Mesozoic plants from the
Transbaikalian locality Chernovskie Kopi. Paleontol J 39:628633.

Vasilenko DV, AP Rasnitsyn 2007 Fossil oviposition of dragonflies: review and interpretation. Paleontol J 41:1156-1161.

Veevers JJ 2004 Gondwanaland from 650-500 Ma assembly through $320 \mathrm{Ma}$ merger in Pangea to $185-100 \mathrm{Ma}$ breakup: supercontinental tectonics via stratigraphy and radiometric dating. Earth Sci Rev 68:1-132.

Yao X, TN Taylor, EL Taylor 1993 The Triassic seed cone Telemachus from Antarctica. Rev Palaeobot Palynol 78:269-276.

1997 A taxodiaceous seed cone from the Triassic of Antarctica. Am J Bot 84:343-354. 